\section{Studia \\ z Filologii Polskiej \\ i Słowiańskiej}

DOI: $10.11649 /$ sfps.2002
Studia z Filologii Polskiej i Słowiańskiej, 55

Warszawa 2020

Article No. 2002

Citation:

Szulc, A. (2020). „Obym się rozradował w rozradowaniu ludów Twoich": Rzecz o konstrukcjach pleonastycznych w cerkiewnosłowiańskich redakcjach Księgi Psalmów. Studia z Filologii Polskiej i Słowiańskiej, 55, Article 2002. https://doi.org/10.11649/ sfps.2002

Arleta Szulc

(Uniwersytet Mikołaja Kopernika w Toruniu)

\title{
„Obym się rozradował w rozradowaniu ludów Twoich". Rzecz o konstrukcjach pleonastycznych w cerkiewnosłowiańskich redakcjach Księgi Psalmów
}

\section{Przedmiot, cel, podstawa opracowania}

Niniejsze opracowanie inspirowane jest artykułem Profesora Leszka Moszyńskiego pt. Pierwsze przejawy samodzielnego życia biblijnych struktur stylistycznych $w$ języku staro-cerkiewno-słowiańskim, opublikowanym w roku 1990 na łamach 26. tomu „Studiów z Filologii Polskiej i Słowiańskiej” (Moszyński, 1990, ss. 187-196), a zwłaszcza tą jego częścią, w której Profesor, powołując się na ustalenia prof. Moshé Altbauera (zaprezentowane w referacie wygłoszonym na II Letnim Kolokwium Starobułgarystyki w Sofii w sierpniu 1980 roku), zwraca uwagę na stylistyczne kalki hebrajskie w staro-cerkiewno-słowiańskim Psatterzu synajskim. Obejmują one 13 konstrukcji pleonastycznych przekalkowanych do Septuaginty (LXX) i dalej do Psałterza synajskiego (Ps: 4:[6]5, 18[17]:45, 35[34]:1, 38[37]:5, 44[43]:2, 68[67]:19, 79[78]:12, 106[105]:5, 106[105]:14, $119[118]: 4,119[118]: 154,125[124]: 4,137[136]: 8)$ oraz 2 kalki pleonazmu hebraj-

This is an Open Access article distributed under the terms of the Creative Commons Attribution 3.0 PL License (creativecommons.org/licenses/by/3.0/pl/), which permits redistribution, commercial and non-commercial, provided that the article is properly cited. (c) The Author(s) 2020.

Publisher: Institute of Slavic Studies, Polish Academy of Sciences

[Wydawca: Instytut Slawistyki Polskiej Akademii Nauk] 
skiego nieznane LXX, lecz w scs. psałterzu obecne (Ps: 27[26]:3, 136[135]:13) (por. Moszyński, 1990, ss. 195-196). Wszystkie te konstrukcje zdecydowano się tutaj zestawić z odpowiadającymi im konstrukcjami w paralelnych kontekstach wybranych reprezentantów psałterzowych redakcji cerkiewnosłowiańskich ${ }^{1}$. W porównaniach uwzględniono także 9 dodatkowych pleonazmów, 7 w obrębie Ps 139[138]-151 (Ps: 139[138]:21, 139[138]:22, 144[143]:6, 144[143]:12, 144[143]:13, 147:18[7], 151:4), które w wykazie Moszyńskiego i Altbauera z oczywistych względów nie mogły być odnotowane ${ }^{2}$, oraz 2 (najwyraźniej przeoczone przez Profesorów) w Ps 14[13]:5 i 50[49]:14².

Celem porównań było zbadanie zachowawczości użyć rozpatrywanych konstrukcji wyekscerpowanych z tekstu scs. Psałterza synajskiego w młodszych od niego psałterzach cs. (zob. wykaz (s)cs. oraz gr. i hebr. tekstów źródłowych na końcu artykułu), a także bliższe przyjrzenie się kilku wyselekcjonowanym z porównywanych psałterzy kontekstom pleonazmy zawierającym.

Przy opracowaniu prezentowanego materiału badawczego posłużono się elektroniczną bazą danych Kata Biblon (Kata Biblon, b.d.) (Strong w LXX i NT; Occurrences in the LXX) oraz pozycjami leksykograficznymi, jak:

G-PSS, 1890/2015,

H-PiA-PSS, 1890/2017,

СиОСП, 1898/1993,

ПЦ-СС ${ }_{1-2}, 1900 / 1998$,

ПС, 1903/1992,

SJS/CCЯ, 1958-1997/2006,

$\mathrm{P}_{\mathrm{p}} \mathrm{B}, 1993 / 1997$,

WSG-PNT, 1995,
KB, 1996,

SSB, 1996/1998,

CC, 1999,

SG-P ${ }_{1-2}, 2000-2001$,

$\mathrm{KH}-\mathrm{K}_{\mathrm{d}} \mathrm{BH}, 2000 / 2005$,

WSH-PiA-PST, 2001/2008,

$\mathrm{SJS}_{\mathrm{ac}}, 2010-2016$,

1 Posłużono się redakcyjną klasyfikacją znaną przede wszystkim z publikacji C. M. MacRobert (zob. np. MacRobert, 1990, 1993, 1998, 2005) oraz F. Thomsona (zob. np. Thomson, 1998), rezygnując z klasyfikacji starszych, zob. np. Погорелов, 1901, ss. XXXIV-XXXVII; Чешко, 1981, ss. 79-85, 1982, ss. 60-93, 1988, ss. 217-230; Карачорова, 1985, ss. 34-38. Wyjaśnienia co do klasyfikacji redakcyjnej znaleźć można we wcześniejszych opracowaniach autorki, zob. np. Szulc, 2018, s. 1, przypis 3. Odnośnie do wykorzystywanej bazy porównawczej, zob. także np. Szulc, 2018, s. 2, przypis 5.

2 Tekst tej grupy psalmów nie był jeszcze badaczom znany. Końcowa część Psałterza synajskiego, od Ps 138, odnaleziona razem z innymi rękopisami w 1975 r. w monasterze Św. Katarzyny na Górze Synaj, wydana została fotograficznie w roku 1988 przez I. C. Tarnanidisa, a w przedruku cyrylickim w roku 1997 przez F. V. Mareša.

${ }^{3}$ Tu konstrukcja pleonastyczna występuje tylko w psałterzach (s)cs. i w ich greckim wzorcu. 
a także:

$$
\begin{aligned}
& \text { БС } \Gamma_{\text {инт. }} \text {, b.d., } \\
& \text { БСГл }{ }_{\text {инт., }} \text {, b.d., } \\
& \text { БСН }{ }_{\text {инт. }} \text {, b.d. }
\end{aligned}
$$

\section{O pleonazmie i tautologii - uwagi ogólne}

Zanim przejdziemy do zasadniczych rozważań nad występowaniem pleonazmów w (staro-)cerkiewnosłowiańskim, greckim i hebrajskim Psałterzu, wyjaśnijmy, czym właściwie jest pleonazm.

O pleonazmie i zbieżnej z nim tautologii M. Majewski w monografii Jak przekłady zmieniaja sens Biblii... O teorii i praktyce tłumaczenia Biblii (Majewski, 2013) pisze:

Pleonazm to wyrażenie, w którym jedna część wypowiedzi zawiera te same treści, które występują w drugiej części, np. 'masło maślane', 'akwen wodny' czy 'zabić się na śmierć'. Tautologia polega na konstrukcji, w której wyrazy również powtarzają swoje znaczenie, np. 'źródło i geneza zjawiska' (choć częściej w relacji współrzędnej niż podrzędnej). W myśleniu semickim występuje specyficzne zjawisko powtarzalności rdzeni lub sensów, które moglibyśmy przez daleką analogię określić konstrukcjami pleonastycznymi/tautologicznymi. W Biblii ST (zresztą jest tak i we współczesnym hebrajskim) wielokrotnie pojawiają się złożenia typu: halam halom (śnił sen), wajjomer lemor (powiedział mówiąc), hata hattaot (zgrzeszył grzechami), sza'al sze'ela (pytał pytanie) itd. Jest to bardzo popularna i konwencjonalna konstrukcja w języku hebrajskim. [...] semici nie widzieli nic niestosownego w powtarzaniu - być może dlatego, że dla opowiadającego było to ułatwienie w pamięciowym opanowaniu tekstu, a poza tym na pewno dodawało emfazy i ładnie brzmiało (Majewski, 2013, s. 133).

W Wykładach ze stylistyki autorstwa D. Zdunkiewicz-Jedynak (Zdunkiewicz-Jedynak, 2010), w rozdziale 15. Estetyczne kategorie oceny stylu wypowiedzi w punkcie 15.3. Estetyka i logika, pleonazm definiuje się jako „Związek wyrazowy, w którym człon gramatycznie podrzędny częściowo powtarza treść wyrazu gramatycznie nadrzędnego” (por. np. „wyrażenia: [...] *potencjalne możliwości, [...] * wzajemna kooperacja, [...] * ponowne odnawianie się, [...] zwroty: [...] * wracać $z$ powrotem, ${ }^{*}$ mieć stuszna racje, [...] ${ }^{*}$ nadal kontynuować, [...] itp."), tautologię zaś jako:

połączenie wyrazów znaczeniowo tożsamych lub taką konstrukcję zdaniową, w której gramatycznie niepowiązane ze sobą bezpośrednio, często oddalone, 
człony powielają dokładnie tę samą treść, np.: [...] *z kolei, następnie; [...] * wiele licznych (wad); [...] ^jednocześnie, w tym samym czasie [...] (Zdunkiewicz-Jedynak, 2010, s. 207).

Podkreśla się, że owe zazwyczaj „niecelowe powtórzenia tej samej treści w różnych wyrazach jednego zdania” są „szczególnymi językowymi śladami niedostatków logicznych w tekście”. Stojąc „w sprzeczności z zasadą ekonomii i precyzji myślenia, [...] często prowadzą do niepotrzebnego gadulstwa”, a „[p]rzyczyną ich powstawania jest głównie nieuwaga lub niedostateczna znajomość znaczenia wyrazu" (Zdunkiewicz-Jedynak, 2010, s. 206). Zdarza się i tak, że:

[n]iektóre pleonazmy mogą być czasem użyte w tekście celowo i służyć przede wszystkim emfazie, czyli podkreśleniu pewnych treści, wyeksponowaniu jakiegoś istotnego, zdaniem mówiącego, elementu znaczenia wyrazu nadrzędnego, emocjonalnemu zintensyfikowaniu wypowiedzi, np. zupetnie pusty, [...] styszeć na własne uszy, [...] kompletne fiasko, [...]. Znaczeniowa nadmiarowość jest uzasadniona także w sytuacjach, gdy zdanie bez częściowego powtórzenia byłoby niejasne, niejednoznaczne. [...] Także tautologia może być używana przez autora świadomie jako środek wzmacniający ekspresję wypowiedzi lub jako element rytmizujący tekst, dopełniający wypowiedź jakimś członem symetrycznym (np. [...] tylko i wyłacznie, krótko i węzłowato) (Zdunkiewicz-Jedynak, 2010, s. 207) .

W literaturze przedmiotu odnajdujemy wiele wskazań na konstrukcje przypominające te, których dotyczy niniejszy artykuł. Zwróćmy uwagę na niektóre $\mathrm{z}$ nich.

Smutkiem zasmuciłem się, radościa raduję się, to przykłady - wedle słów M. Wolniewicza, komentującego zdanie księdza W. Szczepańskiego na temat przekładowej wierności we współczesnych translacjach Biblii na język polski - będące wynikiem przesadnego oddawania „dwoma lub trzema wyrazami równobrzmiącymi obcej polskiemu językowi hendiadys ${ }^{5}$ tekstu

4 Zob. także definicje/informacje odnoszące się do pleonazmu (też tautologii) w innych pozycjach, np.: Riewzin \& Rozencwejg, 1981, s. 265; SWO, 1995, ss. 869, 1093; EJP, 1999, ss. 280 , 396; EJO, 2003, ss. 438, 594; Arnold \& Choi, 2008, s. 202 [Glossary]; RWO ${ }_{\mathrm{d}} \mathrm{PŚ} w, 2012$, s. 50; Briks, 2013, s. 85 [Słownik pojęć gramatycznych]; Кузова, 2013, ss. 113-122.

${ }_{5}$ Zob. hasło hendiadys, np. w Briks, 2013, s. 84 [Słownik pojęć gramatycznych]: „figura stylistyczna polegająca na przedstawieniu jednego pojęcia przez dwa wyrazy połączone współrzędnym spójnikiem”. 
greckiego" (Wolniewicz, 1994, s. 23). Analogiczne konstrukcje nie zdobyły wśród współczesnych tłumaczy polskich uznania. W odniesieniu do tych i innych semityzmów biblijnych, czytamy:

Tłumacze Nowego Testamentu rozróżniają semityzmy, które już przyjęły się w języku polskim i są zrozumiałe, np. Król królów, wieki wieków, i takie, które jeszcze trwają, a rażą w języku polskim, jak np. pożądaniem pożądałem, uradowali się radością, oraz takie, których nie da się przełożyć na język polski, np. Syn Światłości. Semityzmy pierwszej i trzeciej grupy tłumacze pozostawiają. Natomiast znajdujące się w grupie drugiej oddają polskimi zwrotami: gorąco pragnałem, uradowali się bardzo. Participia grafica i pleonazmy należące do tej grupy pomijają albo jakoś zaznaczają ich obecność. [...] „Zagadnienia semityzmów nie można rozstrzygać jednocześnie, a to z kilku względów. Niektóre semityzmy przyjęły się już na stałe w języku polskim, inne znowu nie znajdują odpowiednika [...]" (Wolniewicz, 1994, s. 28).

L. Moszyński, charakteryzując Biblię w przekładzie Szymona Budnego, zauważa, że przyjęta tu:

zasada tłumaczenia słowo w słowo spowodowała pojawienie się w tekście wielu hebraizmów stylistycznych, jak np. zwroty imiesłowowe typu: umierając umrze (Ez 18.13), gardzac wzgardza (Ct 8.7), będac było (Ez 1.3.), zabijając zabili (Ier 26.19), ginac wyginiecie (Dt 8.19) itd., albo wyrażenia gerundialne typu: zadrża zadrżeniem (Ez 27.35), noszeniem noszeni bywaja (Ier 10.5), czarujacy czarowaniem (Dt 18.11) itd. lub z innymi rzeczownikami, jak np. płakać będę w płaczu (Is 16.9), przysięga poprzysiagt (1. Sm 14.28), też ze wzmocnieniem typu: płakali płaczem wielkim (Idc 21.2), zapalitem się zapaleniem wielkim (Za 8.2) itp. (Moszyński, 2009, ss. 182-183).

Przykłady interesujących nas konstrukcji podaje również A. Łuczak przy okazji omawiania problemu rozwiązywania hebraizmów i arameizmów w NT S. Murzynowskiego, stwierdzając, że:

Cechą tzw. stylu biblijnego jest częste występowanie w bliskim sąsiedztwie tego samego określenia. Powtarzanie wyrazów o tym samym rdzeniu jest charakterystyczne dla języków semickich. Zasadniczo języki grecki i łaciński, podobnie jak polski, unikają tego rodzaju powtórzeń i dążą do urozmaicenia. Chodzi m.in. o takie połączenia wyrazowe, jak zestawienie czasownika z rzeczownikiem utworzonym od tego samego tematu [tu, w przypisie 6. dodaje: „Również w grece klasycznej istniała konstrukcja accusativus tzw. biernika wewnętrznego (figura etymologica). Accusativus ten jest utworzony od tego samego tematu co czasownik, przy czym zawsze określony jest przez przydawkę. 
Acc. biernika wewnętrznego występuje tylko przy czasownikach nieprzechod-

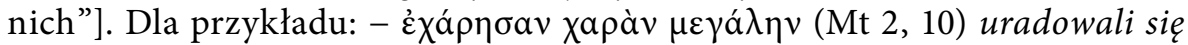

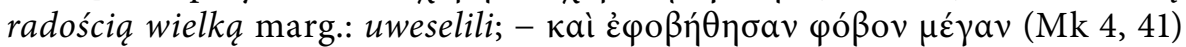
a oni się bali bojaźnia wielką marg.: przelękli; (Łk 2, 9) I polękli się bojaźnia

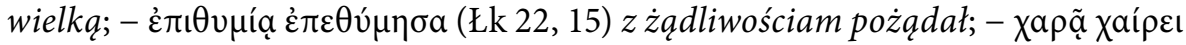
(J 3, 29) wielmi się weseli marg.: weselem albo radością (Łuczak, 1992, s. 227).

P. Briks w przewodniku po hebrajskim tekście Księgi Jonasza (Briks, 2013) wyodrębnia wśród innych bardzo częstą w języku hebrajskim konstrukcję wzmacniającą, tzw. cognate accusative („,biernik kognatywny/pokrewny”).

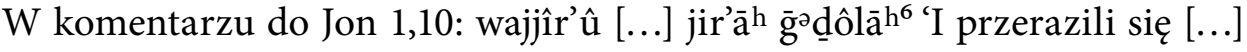
przerażeniem wielkim' Briks pisze:

Można „przerazić się strachem” albo „ucieszyć radością”. Tego typu konstrukcje należy rozumieć jako „bardzo się przestraszyć” albo „ogromnie się ucieszyć”, choć faktycznie tego typu tłumaczenie nie oddaje całej ekspresji takiej figury stylistycznej (Briks, 2013, s. 28).

Z biernikiem kognatywnym mamy również do czynienia, jak wskazuje P. Briks, w Jon 1,16: wajjîr' û [...] jir'āh ('̄ədôhlāh) 'I przerazili się [...] przerażeniem (wielkim)' [...] wajjizbəhûu zeḅah 'I ofiarowali ofiarę' [...] wajjiddərû nəọārîm 'i ślubowali śluby' -

wszystkie trzy czasowniki [...] wzmocnione są przez pochodzące od nich rzeczowniki („zlękli się lękiem”, „ofiarowali ofiary”, „ślubowali śluby”) (Briks, 2013, s. 36),

a także w Jon 4,1: wajjēra 'el jônāh rā'āh ğ’dôlāh wajjiḥar lô 'I rozzłościło Jonasza zło wielkie i rozgniewało go', gdzie zastosowane zostało

podwójne wzmocnienie dla wyrażenia oburzenia Jonasza: „rozgniewał/rozpalił go gniew" (cognate accusativ, ten sam zwrot patrz: Ne 2, 10), a ten gniew był nie byle jaki, ale wielki. Druga część wersetu jest powtórzeniem (czyli kolejnym wzmocnieniem) tej samej myśli (Briks, 2013, s. 68)

oraz w Jon 4,6: wajjiŝmah [...] ŝimḥāh ("g̊dôlāh) 'I radował się [...] radością (wielką)', w komentarzu do którego, czytamy, że jest to

${ }^{6}$ W przytaczanych przykładach hebrajskich, tu i dalej, zamiast zapisu oryginalnego stosuje się transliterację, wg odpowiednich ksiąg H-PST (Pięcioksiąg), 2017; H-PST (Pisma), 2009; H-PST (Prorocy), 2008. 
znane już z poprzednich wersetów podwójne wzmocnienie czasownika poprzez powtórzenie rdzenia $\mathrm{w}$ formie rzeczownika i przymiotnik g’̀dôlāh (cognate accusativ[e] [...]) (Briks, 2013, s. 76).

O bierniku wewnętrznym (internal accusative) bądź, technicznie (z uwagi na identyczność rdzenia czasownika i rzeczownika jako dopełnienia), bierniku pokrewnym (cognate accusative) wspominają także B. T. Arnold i J. H. Choi, podając m.in. takie jego przykłady:

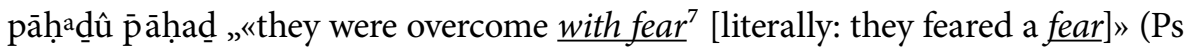
14:5)”; hẹeț’ hạațāh jrûšālaim „ "Jerusalem sinned grievously ${ }^{8}$ [literally: sinned a sin]]”

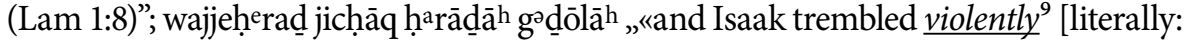
trembled a great trembling]» (Gen 27:33)"; wajjak jhwh ('adōnāj) bāām makkāh rabbāh $\mathrm{m}^{2} \mathrm{o} \mathrm{o}$, , ,and YHWH struck the people with a very great plague ${ }^{10}[$ literally: struck ... with a very great striking]» (Num 11:33) (zob. Arnold \& Choi, 2008, ss. 15-16, p. (c)).

M. Tomal analogiczny biernik nazywa „niezależnym”: accusativus absolutus (zob. Tomal, 2000). Na jego temat pisze: „Jest to dość częsta biblijna forma wyrażania okolicznika sposobu. Występuje on w formie imienia powtarzającego znaczenie orzeczenia: [...] hiț’awwû ta’ăwā 'pragnęli (dosł. 'pragnęli pragnieniem')' (Lb 11, 4)” (Tomal, 2000, s. 151) ${ }^{11}$. Konstrukcja ta, obok innych, por. np. infinitivus absolutus/constructus (Tomal, 2000, ss. 49-51) zasadniczo pełni funkcję intensyfikującą, wzmacniającą ${ }^{12}$.

7 W tłumaczeniu na język polski (wg H-PST (Pisma), 2009 [Księga Psalmów], s. 17): 'zadrżeli (ze) strachu'. To samo można by oddać jako 'przestraszyli się strachem'.

${ }^{8}$ W tłumaczeniu na język polski (wg H-PST (Pisma), 2009 [Lamentacje], s. 538): 'Grzechem zgrzeszyła Jerozolima’.

9 W tłumaczeniu na język polski (wg H-PST (Pięcioksiąg), 2017 [Księga Rodzaju], s. 102): 'I przeraził się Izaak przerażeniem wielkim'.

${ }^{10}$ W tłumaczeniu na język polski (wg H-PST (Pięcioksiąg), 2017 [Księga Liczb], s. 574): 'i uderzył JHWH w lud plagą wielką bardzo'. To samo można by oddać 'i uderzył JHWH w lud uderzeniem (ciosem) wielkim bardzo'.

11 W H-PST (Pięcioksiąg), 2017 [Księga Liczb], s. 569: hiṭ’awû ta’awāh 'zapragnął żądzy'.

12 O niektórych środkach służących intensyfikacji, w tym o konstrukcjach z powtórzeniem rdzenia/formacji konkretyzujących ten sam rdzeń (tzw. figura ethymologica), zob. też np. Bieńkowska, 2002, ss. 98-99; Kowalska, 2003, np. ss. 76-81 i in.; Termińska, 2015, s. 173 i nn. [Rozdział XV: Intensivum]. Zob. przykłady emfatycznych figur stylistycznych również w Siwek, 2013, np. s. 111 [Uwagi do tekstu, wiersz 28], s. 455 [Uwagi do tekstu, wiersz 7], s. 483 [Komentarz do Jr 27,16]. Por. także generalnie intensyfikujące (wzmacniające) konstrukcje $\mathrm{z}$ infinitivem absolutem $\mathrm{w}$ : Altbauer, 2002a, ss. 67-70, 2002b, ss. 43-47, 2002c, ss. 61-63. Przykłady m.in. tzw. emfatycznego (emphatic) infinitivu absolutu zob. również w Arnold \& Choi, 2008, ss. 74-75 (p. (b)). 


\section{Przykłady pleonazmów w psałterzowych redakcjach cs.}

Przyjrzyjmy się teraz kilku wybranym kontekstom z poświadczonym użyciem konstrukcji pleonastycznych w porównywanych cs. redakcjach Księgi Psalmów.

Strukturą tautologiczną (pleonazmem) posłużono się w Ps 4:[6]5, kiedy na miejscu gr.

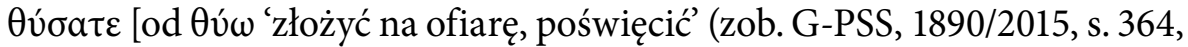

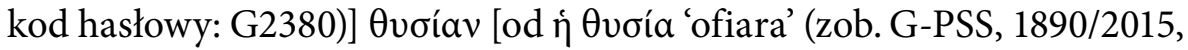
s. 364, kod hasłowy: G2378)],

oddającego hebr.

ziḅhû [od zābِah 'składać (na) ofiarę’ (zob. H-PiA-PSS, 1890/2017, ss. 280-281, kod hasłowy: H2076)] ziḅhê [od zebaha 'ofiara (przymierza, paschalna, coroczna, dziękczynna') (zob. H-PiA-PSS, 1890/2017, s. 281, kod hasłowy: H2077)],

zastosowano

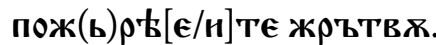

Nasuwa się pytanie: dlaczego nie zadowolono się użyciem jedynie odpowiedniej formy czasownika (po)žrěti/-žrıti/-žbrti, bez zbędnego, jak wydawać by się mogło, dopełnienia go właściwą formą rzeczownika žrbtva ${ }^{13}$, skoro, tak samo jak jego gr. i hebr. ekwiwalent, już sam w sobie oznacza 'składaćl złożyć (na) ofiarę’? Najpewniej dlatego, że analogiczny zwrot pleonastyczny obecny jest w bezpośrednim źródle (wzorcu) greckim oraz pośrednim, hebrajskim. W rozpatrywanym kontekście chodzi o złożenie Panu ofiary ${ }^{14}$

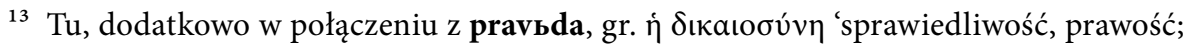
prawda', hebr. cedeq 'sprawiedliwość, słuszność, prawość'.

14 „Ofiary stanowiły integralny element kultu religijnego Izraela; obraz ten przenika biblijne przesłanie od dziejów Kaina i Abla aż do Księgi Apokalipsy. [...] W ST kult i ofiara są ze sobą nierozerwalnie związane. Pięcioksiąg (szczególnie Kpł 1-7) wymienia kilka rodzajów ofiar: ofiarę całopalną, która stanowiła kluczowy element kultu w ramach świątyni; ofiarę za grzech, prowadzącą do odnowienia człowieka lub miejsca, które stało się nieczyste; ofiarę przebłagalną, która była zadośćuczynieniem za nieświadomie wyrządzone zło, i ofiarę dziękczynną, wyrażającą wdzięczność wobec Boga. Każda ofiara miała odmienny charakter, lecz wszystkie miały upamiętniać lub odnowić więź pomiędzy Bogiem i Jego 
przebłagalno-dziękczynnej, jako zadośćuczynienia za wszelkie dobro od Niego „bez zasług” doznane. Psalmista z pełną determinacją domaga się od bałwochwalców (czcicieli bożków) oddania Jahwe należnej sprawiedliwości, której zewnętrzną oznaką jest ofiara ${ }^{15}$. Posłużenie się tutaj pleonazmem ma swe uzasadnienie - ma wzmocnić, podkreślić, zaakcentować i niejako usankcjonować myśl zawartą we fragmencie psalmu. Wyrażone tu żądanie nie wybrzmiałoby w słowiańskim tłumaczeniu poświadczonym w porównywanych reprezentantach cs. Księgi Psalmów tak dobitnie (kategorycznie), gdyby zamiast omawianej struktury pleonastycznej użyto w nich samego požrě[e]te/požrite bądź zestawiono žrbtva $\mathrm{z}$ innym czasownikiem $\mathrm{w}$ trybie rozkazującym, np. z dati, vъznesti itp.

ludem. Ludzie zawsze składali ofiary, aby zdobyć przychylność Boga lub Go przebłagać. Istotne było także to, co składano. [...] W księgach prorockich ofiary nakazane przez Prawo zostały przedstawione w szerszej perspektywie. Miały też mniejszą wartość aniżeli ofiara serca - sprawiedliwe postępowanie. [...] Jezus, podobnie jak prorocy, podkreślał fakt, że Bóg domaga się od człowieka ofiary serca i że bez zmiany postawy i postępowania każda materialna ofiara jest pozbawiona znaczenia [myśl ta doskonale koresponduje z rozważanym psalmowym kontekstem - A. S.]. [...] Ludy niemal wszystkich kultur starożytnych składały ofiary, aby pozyskać przychylność bogów, a nawet zachować ich przy życiu (np. w Mezopotamii). Religia Hebrajczyków nie była pod tym względem wyjątkiem, chociaż pogląd, że ofiary są pokarmem dla Jahwe (Kpł 21,6), jest stosunkowo rzadki i stanowi nawiązanie do innych religii, nigdy też nie był przedstawiany poważnie (Ps 50, 12-14). Ofiary były raczej darami dla uczczenia Boga. Krew, ogień i dym to najczęstsze obrazy ofiar, które pojawiają się w pismach hebrajskich. Ofiary symbolizowały również fakt, że ludzie wszystko zawdzięczają Bogu. W istocie, z powodu grzechu ludzie są $\mathrm{Mu}$ winni swoje życie, a ofiara zajmuje ich miejsce. Zwierzę ponosi śmierć zamiast człowieka. Pogląd ten znalazł wyraz w śmierci Jezusa na krzyżu" (SSB, 1996/1998, ss. 633-364, hasło: Ofiara). Por. także hasła: Жертва Жертва благодарения - Жертва возлияния - Жертва всесожжения - Жертва за грех и жертва повинности - Жертва мирная - Жертва по обету - Жертва ревнования -

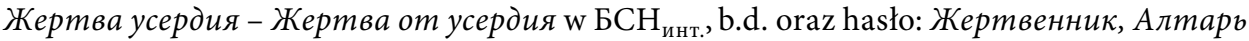
w БСГл

15 Por. komentarz do Ps 4:6 w ТП(Пал.) «приобретайте правду, делайте правду и ее принесите в жертву Богу» (Св. Афан. и св. Злат.). «Сими словами, - говорит бл. Феод., - Давид отметает подзаконное служение, как излишнее, узаконяет же приносить жертву правды; потому что приобретение правды, с присоединенным к ней упованием на Бога, приятнее Богу ста и тысячи волов». Блаж. Феодорит разумеет будущие новозаветные времена, а при Давиде все богоучрежденные жертвы были важны, нужны и обязательны”. Zob. też BPK, 2017, s. 723, przypis 5: „Sprawiedliwość w Biblii Starego Testamentu ma na ogół wymiar moralny, bo chodzi o postępowanie według prawa Bożego, w tym zgodnie z Dekalogiem. Tutaj hagiograf podkreśla, że człowiek może osiągnąć sprawiedliwość dzięki pomocy Boga”. 
W Ps 38[37]:5 gr. pleonazm

( liwy, surowy; brutalny, okrutny, bezlitosny' (zob. G-PSS, 1890/2015, s. 135,

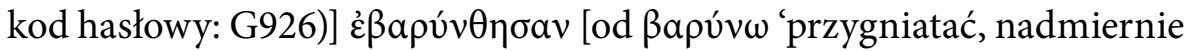
obciążać' (zob. G-PSS, 1890/2015, s. 135, kod hasłowy: G925)],

odpowiadający hebr.

(kəmaŝāa') knābeēd ['ciężki, wielki, olbrzymi; trudny, uciążliwy' (zob. H-PiA-

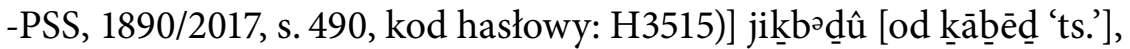

oddano przez

(врНМА) ТњАжько отегот'КшњА,

utrzymując przez to wysoką siłę ekspresji, pożądaną dla zobrazowania sytuacji, w jakiej znalazł się przytłoczony własnymi winami nieszczęśnik (nieszczęśliwy grzesznik).

Uzasadniony greckim i hebrajskim źródłem zwrot pleonastyczny porównywane cs. redakcje psałterzowe zastosowały także w Ps 106[105]:5:

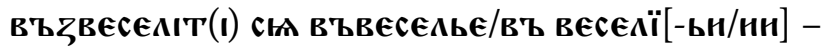

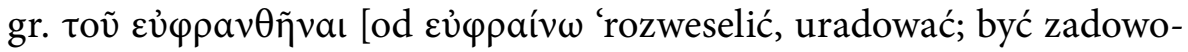
lonym, weselić się, radować się, rozkoszować się’ (zob. G-PSS, 1890/2015,

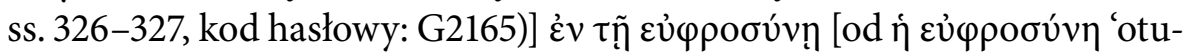
cha, radość, wesele’ (zob. G-PSS, 1890/2015, s. 327, kod hasłowy: G2167)],

hebr. liŝmōaḥ [od ŝāmaḥ 'radować (się), cieszyć (się); unosić się radością; powodować radość (zob. H-PiA-PSS, 1890/2017, s. 1095, kod hasłowy: H8055)] bəŝimḥat [od ŝimḥāh 'radość, wesołość, uciecha, zadowolenie; pomyślny skutek, szczęśliwy obrót spraw' (zob. H-PiA-PSS, 1890/2017, s. 1095, kod hasłowy: H8057)].

Wyeksponowane tu zostało głębokie pragnienie dostąpienia udziału („rozradowania się”) w „radości”, tj. wspólnocie ludu wybranego z jego Panem ${ }^{16}$, a w szerszej

16 „Radość jest konsekwencją życia w społeczności z Bogiem. Nie można jej znaleźć, gdy się jej szuka lub uzna za cel. Musi zostać darowana przez Boga [...]. Dlatego należy ją przyjąć $\mathrm{w}$ postawie wiary razem $\mathrm{z}$ darem zbawienia [...]. W ST radość towarzyszy doświadczaniu Bożej 
perspektywie - w Królestwie Niebieskim. Analizowany zwrot przywodzi na myśl słowa z Przypowieści o talentach (Mt 25, 21.23): „,wejdź do radości twego pana”, które odnoszone są do królestwa Bożego (por. KKB, 1990/2001, s. 972; zob. też komentarz

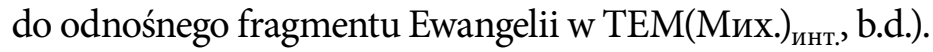

W celu ekspozycji odpowiednich znaczeń zwrotami pleonastycznymi posłużono się i w innych fragmentach psalmów, np. w Ps 106[105]:14, w którym mowa o niewdzięcznych Hebrajczykach na pustyni, owładniętych żądzą „chleba powszedniego", wystawiających swego Boga na próbę oraz w Ps 139[138]:22, w którym psalmista z całą mocą wypowiada swą nienawiść do tych, którzy nienawidzą Pana.

W Ps 106[105]:14 na miejscu gr.

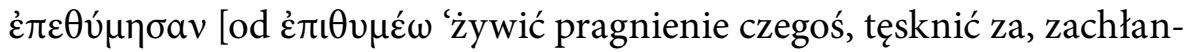
nie czegoś pragnąć; pożądać, zabiegać o rzeczy zakazane’ (zob. G-PSS,

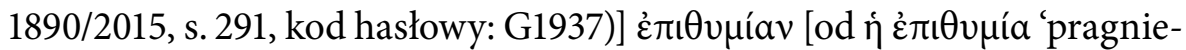
nie, pożądanie, tęsknota; pragnienie tego, co zakazane, żądza' (zob. G-PSS, 1890/2015, ss. 291-292, kod hasłowy: G1939)]

i hebr.

wajjiṭ̂awû [od 'āwāh 'pragnąć, skłaniać się ku, pożądać, wyczekiwać tęsknie, życzyć sobie, chcieć; łaknąć, pragnąć (pokarmu i napoju)' (por. H-PiA-PSS, 1890/2017, s. 26, kod hasłowy: H183)] ța’a ${ }^{\prime}$ h ['pragnienie, pożądanie, życzenie, tęsknota serca; żądza, chciwość; rzecz pożądana, upragniona; przedmiot pragnienia, pożądania' (zob. H-PiA-PSS, 1890/2017, ss. 1140-1141, kod hasłowy: H8378)]

cs. redakcje użyły zestawień:

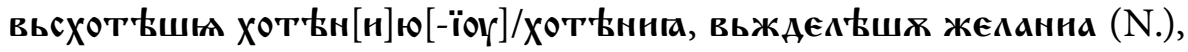
похот Вша жеканїю (С.).

We wszystkich (oprócz C.) reprezentujących je psałterzach, zastosowano połączenia form czasownika i rzeczownika opartych na tych samych rdzeniach. W C. rdzenie czasownikowy i rzeczownikowy, choć różnią się formą, są bliskie znaczeniowo. Można zatem przyjąć, że konstrukcja pleonastyczna została w C. zachowana.

obecności [...]. W NT obecność Boga łączy się z osobą Ducha Świętego [...]” (SSB, 1996/1998, s. 855, hasło: Radość). Por. także hasło: Padocmb np. w ПC, 1992, ss. 148-151. 
W Ps 139[138]:22 (s)cs. pleonazm

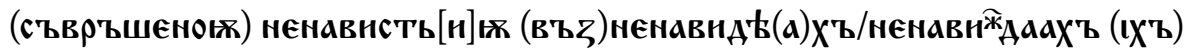
odpowiada analogicznej konstrukcji gr.

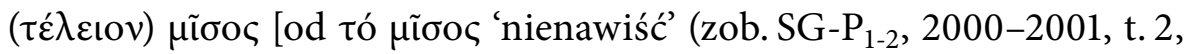

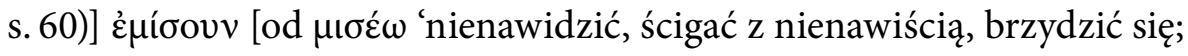
być znienawidzonym, budzącym obrzydzenie’ (zob. G-PSS, 1890/2015, ss. 509-510, kod hasłowy: G3404)] (aủioúc)

i hebr.

(takllîț) ŝin'āh ['nienawiść' (zob. H-PiA-PSS, 1890/2017, s. 1108, kod hasłowy: H8135)] ŝənē'(țîm) [od ŝānē' 'nienawidzić, żywić nienawiść' (zob. H-PiA-PSS, 1890/2017, s. 1108, kod hasłowy: H8130)].

W Ps 144[143]:12 konstrukcja tautologiczna, jak się wydaje dla zaakcentowania podziwu nad córkami Izraela, które „przedstawione [tu zostały] jako solidne kolumny, wspierające strukturę domu, niczym kolumny świątyni” (por. JPII/BXVI, 2006, s. 441 [Komentarz Benedykta XVI do Ps 144 [143], 9-15] ${ }^{17}$ ), poświadczona została jedynie w scs. Psałterzu synajskim, pozostałe zaś psałterze cs., w zgodzie z LXX i pośrednio z BH, z tautologii zrezygnowały, por.

прқкжштены ько оүкжштенне (црквн), ale:

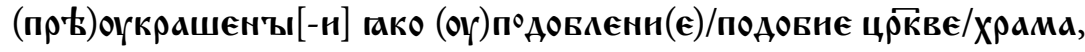
gr.

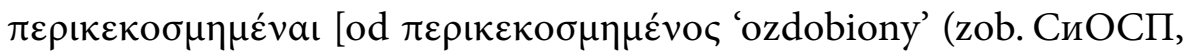
1898/1993, ss. 523-524)] '்́ ónoí $\omega \mu \alpha$ ['obraz, podobieństwo, wyobrażenie' (zob. G-PSS, 1890/2015, s. 550, kod hasłowy: G3667)] vaoũ,

17 Por. także komentarz np. w ТП(Ирин.) $)_{\text {инт. }}$ b.d.: „[...] дщерей уподобляет краеугольному камению, прекрасно истесанному, и составляющему преузорочное здание. В нашем переводе подобие взято или от храма, бывшаго в Иерусалиме, или от скинии, в которой находилися всякаго рода украшения, яко-то: багряница, виссон, сребро, злато, дорогое камение и прочее сему подобное". 
hebr.

məhuțāboôṭ [od hạātab 'ciąć, rzeźbić' (zob. H-PiA-PSS, 1890/2017, s. 327, kod hasłowy: H2404)] tabnît ['wzór, postać, wizerunek' (zob. H-PiA-PSS, 1890/2017, s. 1144, kod hasłowy: H8403)] hêkāl.

(S)cs. pleonazm stał się niezbędny również w Ps 147:18[7], gdzie aby dokładnie oddać gr. konstrukcję

$\pi v \varepsilon v ́ \sigma \varepsilon ı$ [od $\pi v \varepsilon ́ \omega$ 'dmuchać, dąć' (zob. G-PSS, 1890/2015, s. 630, kod hasłowy: G4154)] тò $\pi v \varepsilon \tilde{u} \mu \alpha$ ['ruch powietrza (łagodny powiew), wiatr: dech w nozdrzach bądź ustach; duch (też dusza); Duch Święty' (zob. G-PSS, 1890/2015, ss. 628-629, kod hasłowy: G4151)],

mającą oparcie w paralelnym zwrocie hebrajskim

[w BH użyto zestawienia: jaššēb̄ (od nāšab 'dmuchać, dąć, wiać; spowodować wianie, rozproszyć, przepędzić', zob. H-PiA-PSS, 1890/2017, s. 730, kod hasłowy: H5380) rûhôo (od rûah 'wiatr, oddech, tchnienie, umysł, duch (życia, ośrodek uczuć), Duch Boży', zob. H-PiA-PSS, 1890/2017, s. 994, kod hasłowy: H7307)],

zastosowano połączenie

\section{АЪХКЕТ' $\overrightarrow{A X} \mathbf{Z}$.}

Teoretycznie zamiast $\mathbf{d u x ъ} / \mathbf{d} \mathbf{b x \mathbf { b }}$, by zróżnicować rdzenie czasownika i rzeczownika, mógł zostać tu użyty větrı, ale wówczas znaczenie rozpatrywanego fragmentu psalmu zostałoby spłycone. Nie o zwykły wiatr (jako niezależny żywioł natury) „wiejący, gdzie chce” tak naprawdę chodzi, a o działanie ożywczego Ducha Bożego, za którego przyczyną wszystko się staje, w tym to, że „ciepły wiatr [...] przynosi lato i topi lód - woda deszczowa i strumienie mogą swobodnie spływać, nawadniając ziemię i ją użyźniając” (JPII/BXVI, 2006, s. 459 [Komentarz Jana Pawła II do Ps 147 [146-147], 12-15.19-20 $\left.]^{18}\right)$. W tej części psalmu wyrażona jest myśl, że „Słowo Boże

18 Por. podobny w swej wymowie komentarz do rozpatrywanego fragmentu psalmu w ТП(Лоп.) $)_{\text {инт. }}$ b.d.: „Снег, белый как шерсть вымытых пред стрижкой овец; иней, густой, как пепел от костра; сильный мороз, губящий растительность зимой и опасный для здоровья человека; лед зимой и ручьи весной - все это совершается по воле Господа". 
(Duch Boży/Duch Święty ${ }^{19}$ ) jest [...] sprawcą zimna i ciepła, rytmu pór roku i życia natury. Ludzkość wezwana jest, by uznać i wyrazić wdzięczność Stwórcy za podstawowy dar - wszechświat, który ją otacza, dzięki któremu oddycha, żywi się i utrzymuje przy życiu" (JPII/BXVI, 2006, s. 459 [Komentarz Jana Pawła II do Ps 147 [146-147], 12-15.19-20]).

W tłumaczeniu 4. wersetu niekanonicznego (w BH) Ps 151 porównywane psałterze (s)cs., za LXX, również użyły odpowiedniej konstrukcji tautologicznej:

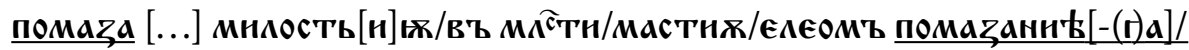 маzаннга}

- gr.

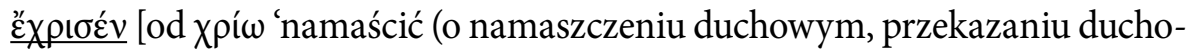
wego daru lub misji)' (zob. G-PSS, 1890/2015, s. 838, kod hasłowy: G5548)]

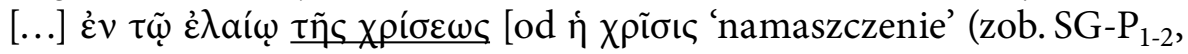
2000-2001, t. 2, s. 522)].

19 „Duch Święty, trzecia osoba Trójcy Świętej, pełni nieprzerwanie rolę tego, który w niewidzialny sposób łączy i pośredniczy między ludźmi a Bogiem. Świadomość obecności Ducha Świętego wyraża się w odmienny sposób w ST i NT, jednak niezmiennie uznawana jest za dowód Bożej obecności. [...] Ruch powstały w wyniku oddechu lub wiatru wskazuje na główną funkcję Ducha Świętego. W hebrajskim tekście ST słowo rûaḥ oznacza «wiatr», «oddech» lub «duch». Słowo to jest zwykle używane na oznaczenie ducha, w tym także Ducha Bożego. Sprawia to, że samo pojawienie się owego słowa sugeruje istnienie związku pomiędzy Duchem i wiatrem oraz oddechem. Chociaż w greckim tekście NT słowo pneuma rzadziej oznacza «wiatr», to forma czasownikowa, pnēo, znaczy «wiać», co sugeruje powyższy związek. Wspólny dla wymienionych terminów jest obraz niewidzialnych sił lub życiowej energii, której źródło trudno dostrzec, lecz jej skutki są wyraźnie widoczne, niekiedy mają nawet dramatyczną formę. [...] Podobnie jak wiatr, [...] stwórcza moc Ducha Świętego przekracza ludzkie siły i pojmowanie" (SSB, 1996/1998, s. 167, hasło: Duch Święty [Wiatr i oddech]). Por. także Briks, 2013, s. 16 [Komentarz do Jon 1,4]: „Słowo rûah ma bardzo szerokie spektrum znaczeń. W ST oznacza najczęściej podmuch, tchnienie, wiatr, ale także życie czy ducha człowieka. Pojawia się także jako określenie tchnienia Boga, ducha lub życia, którego daje. Jest to wyraźne nawiązanie do oddechu jako oznaki życia oraz do wiary, że człowiek pierwsze swoje tchnienie otrzymał od Boga. W wyrażeniu rûah 'elōhîm czy rûah JHWH tradycja chrześcijańska widziała zapowiedź osobowego Ducha świętego”. O Duchu Świętym (Bożym) zob. także ПC, 1903/1992, ss. 48-50, hasło: Духъ Святьй. Zob. również hasło: Дух np. w БСГ инт. b.d. 
Pleonazmu można było tutaj uniknąć, używając połączenia dwuwyrazowego: pomaza [...] mastijo/jeleomъ (tu zamiast jelejemb) [ewentualnie niezgodnie (?) ze wzorcem greckim milostbjo(-ijo)/vъ milosti] zamiast zastosowanego zestawienia trójwyrazowego (zob. wyżej). Jednakże rezygnując z formy (po)mazanija (+ svojego), zrezygnowano by $\mathrm{z}$ bardziej wyrazistego wyeksponowania faktu, że sprawcą namaszczenia Dawida był sam Bóg. Zastanawiające jest, dlaczego psałterze reprezentujące cs. redakcje: archaiczną (pierwszą (S.) razem z redakcją komentarzy Pseudo-Atanazego (B.)), mieszaną (Sr.) i wschodniobułgarską (drugą (F.)) zamiast właściwego jelejb (jelějb)/olějb bądź mastı użyły słowa

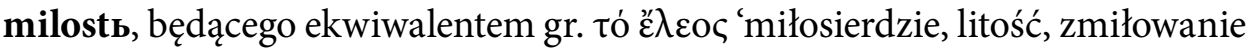

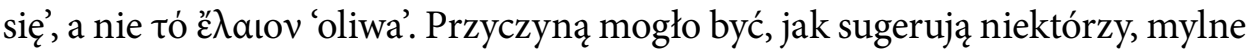
utożsamienie podobnych zewnętrznie, lecz różnych znaczeniowo, greckich wyrazów (por. np. MacRobert, 1990, s. 10; zob. też Szulc, 2000, s. 112, przypis 106). Przyczyna może też tkwić głębiej - olej namaszczenia/namaszczenie oliwą symbolizuje bowiem szczególną życzliwość (upodobanie) wobec namaszczonego (pomazańca) ${ }^{20}$, por. wcześniejszy fragment wersetu 4: „On posłał swojego anioła i zabrał mnie od owiec mojego ojca” oraz werset 5: „Moi bracia są przystojni i wysocy, lecz Pan nie ich upodobał sobie" (zob. LXX $\mathrm{RP}_{\text {P }}$ 2014, s. 983).

Poniżej znajduje się wykaz fragmentów psalmów zawierających konstrukcje pleonastyczne, poświadczonych w porównywanych reprezentantach cs. redakcji Psałterza, wraz z paralelnymi fragmentami w wersjach greckiej i hebrajskiej ${ }^{21}$ :

Ps 4:[6]5 - пожьрь[є]те (пожрнте Sr., Т., С.) жрътвж правьдж (правдъї В., F.;

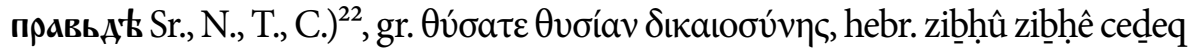

20 Por. komentarz do analizowanego fragmentu psalmu $151 \mathrm{np.} \mathrm{w} \mathrm{ТП(Пал.)})_{\text {инт. }}$ b.d.: „Помаза мя елеем помазания Своего, т.е. помазал елеем Своего Божественного помазания, духовного, сверхъестественного, благодатного; ибо сказано: и почивал Дух Господень на Давиде с того дня и после, т.е. тотчас, непосредственно после помазания священным елеем (ст. 13)". Por. także hasło: Duch Święty [Olej namaszczenia] w SSB, 1996/1998, s. 169: „Według słów Psalmisty namaszczenie oliwą oznacza Bożą obecność i Jego przychylność (Ps 23, 5; 89, 20); Boży wybraniec został namaszczony «olejkiem radości» (Ps 45, 8)”.

${ }^{21}$ Z powodu konieczności ograniczenia objętości artykułu zrezygnowano z przytoczenia polskich tłumaczeń greckich i hebrajskich fragmentów psalmów, odsyłając do odpowiednich źródeł, zob. BT, 1980; H-PST (Pisma), 2009; LXX $_{\mathrm{RP}}$, 2014; BPK, 2017.

22 (S)cs. cytaty psalmowe podaje się w zapisie wg S., warianty leksykalne i gramatyczne zaś - wg najstarszego z porównywanych psałterzy cs., w którym dany wariant został odnotowany; różnic graficzno-fonetycznych generalnie nie uwzględnia się. 


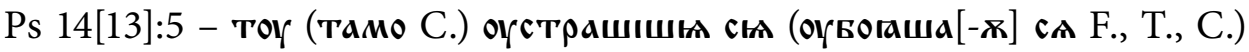
воt $[\mathbf{a}]$ знь[н](ウ)ж (вогазні F., Т.; воазнь N.; страха C.) (w Sr. brak frag-

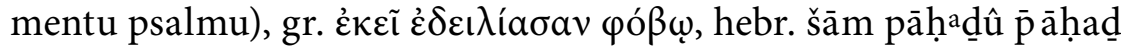

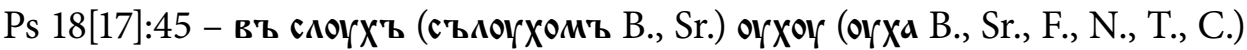

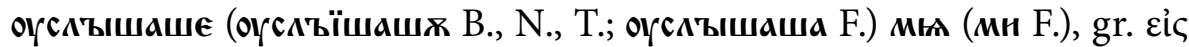

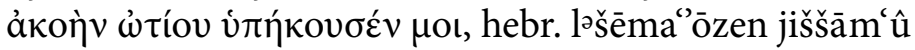

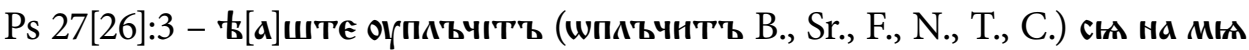

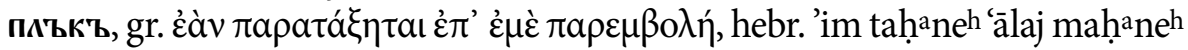

Ps 35[34]:1 - вьзбрани ворнштти(ї)мъ (ворацжа С.) сьа (- N., С.) со[ъ]

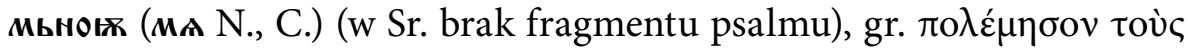
$\pi \mathrm{o} \lambda \varepsilon \mu \mathrm{oṽ} \nu \tau \alpha \dot{\alpha} \varsigma \mu \varepsilon$, hebr. l’ḥam 'eț lọ̣̄amāj

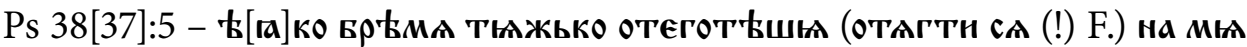

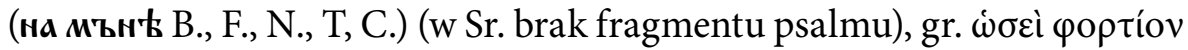

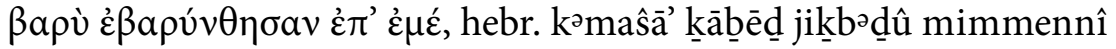

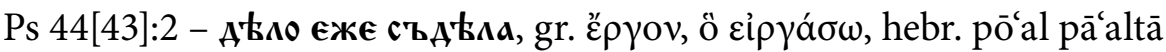

Ps 50[49]:14 - пожърг воу (ввн В., Sr., F., N., Т., С.) жръттвд Хвалд (Хваль[-га]

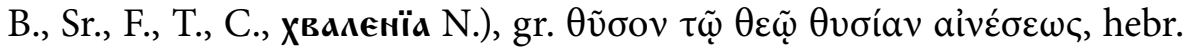
z’bahạ lē’lohîm tôdāāh

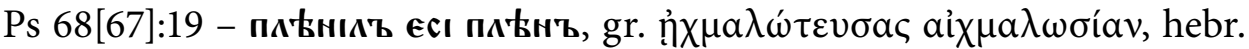
šābîțā ššebîi

Ps 79[78]:12 - поношениемь (поношенне В., Sr., F., N., Т., С.) (+ нХъ В., F., Т.)

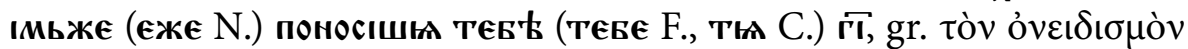

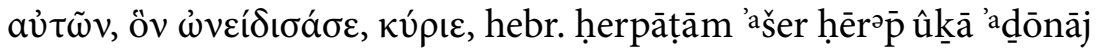

Ps 106[105]:5 - въzвеселіті сы (вь弓веселнт се Sr.) въ веселье (веселї В.,

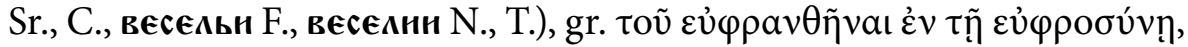
hebr. liŝmōaḥ bəŝimḥaṭ

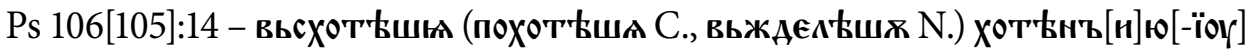

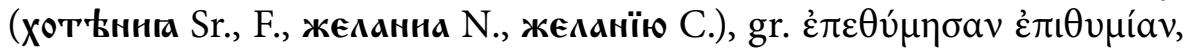
hebr. wajjiț’awû ța’a āh

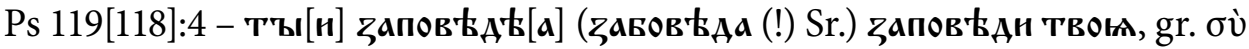

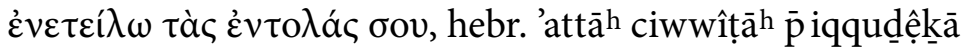

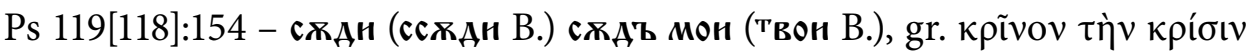

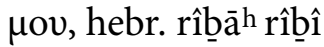

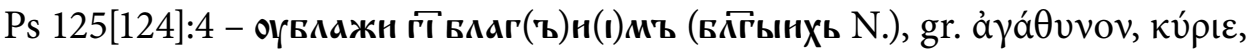

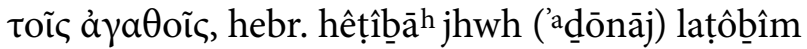




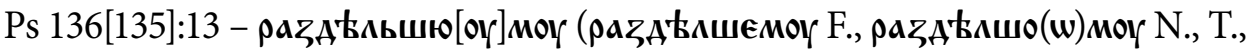

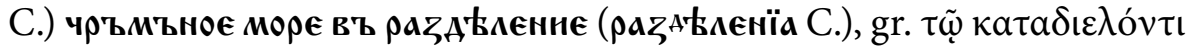

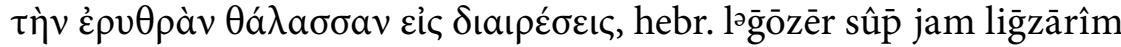

Ps 137[136]:8 - їжє въ弓Аастъ (+ тев' Sr., N., Т., С., тевє F.) въろАа(а)нь[н]є

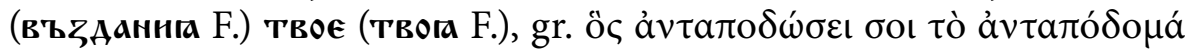
бov, hebr. šệšallem lāk 'eṭ gəmûlēk

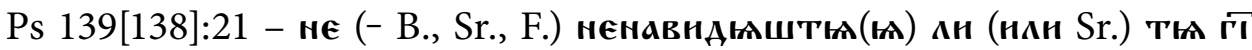

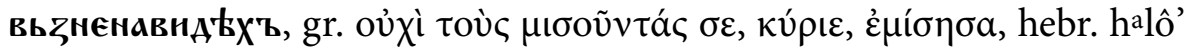
mŝan'ệkā jhwh ('adōonāj) 'eŝnā'

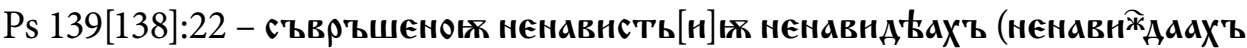

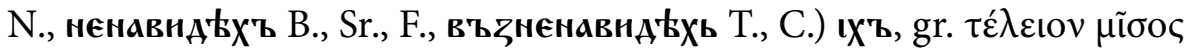

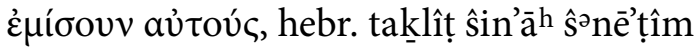

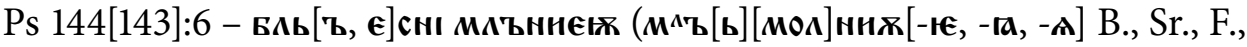

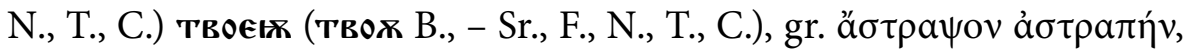
hebr. bərôq bārāq

Ps 144[143]:12 - І прқкжштенъ (прқоүкрашенн[-ы] Sr., N., Т., С., оүкрашенъ F.)

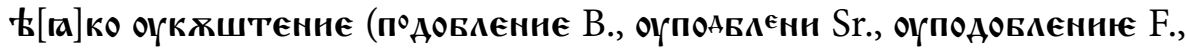

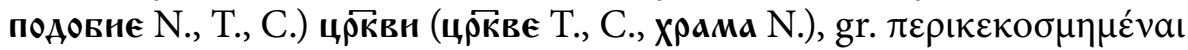

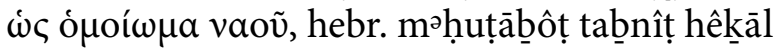

Ps 144[143]:13 - овьцья (овча F.) Іхъ многоплодъ<ны>

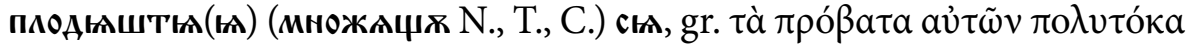
$\pi \lambda \eta \theta u ́ v o v \tau \alpha$, hebr. cōwnēnû ma’alîp ôt mərubbābôt

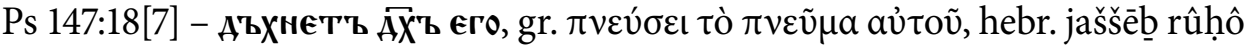

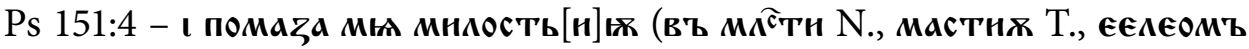

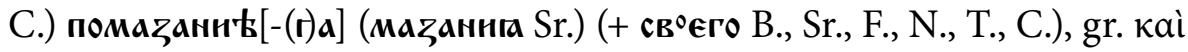

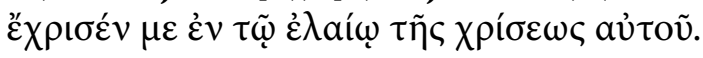

\section{Wnioski}

Porównywane (s)cs. teksty psałterzowe pod względem wystąpień rozpatrzonych konstrukcji pleonastycznych wykazują między sobą wyraźną zgodność. Zawarte w nich pleonazmy:

i. zazwyczaj stanowią połączenie czasownika z rzeczownikiem, opartych (w większości) na tych samych bądź (rzadziej) bliskich znaczeniowo rdzeniach (zob. powtórzenie znaczeń, za LXX, przy odmienności rdzeni 
w Ps 14[13]:5 w S., B., N., C., a w F. i T., tak samo jak w BH, powtórzenie rdzeni; powtórzenie znaczeń w Ps 106[105]:14 w C., a rdzeni w pozostałych psałterzach (s)cs. oraz w LXX i BH; powtórzenie znaczeń w Ps 144[143]:6 we wszystkich psałterzach (s)cs., oddające powtórzenie rdzeni w LXX i BH; powtórzenie znaczeń w Ps 144[143]:13 w N., T., C., za LXX i BH, w pozostałych zaś psałterzach (s)cs. - rdzeni);

ii. charakteryzują się brakiem powtarzalności wystąpień, ewentualnie znikomą powtarzalnością, por. Ps 4:[6]5 i Ps 49[50]:14 (mogą więc zostać uznane za okazjonalizmy);

iii. tak jak ich greckie i hebrajskie wzorce pełnią funkcję ekspresywną (podkreślają, akcentują, eksponują treści wyrażone w psalmowych wersetach);

iv. w swym zastosowaniu uzależnione są od równoległych struktur greckich, podobnie jak pleonazmy greckie od hebrajskich;

v. indywidualizm w zakresie stosowania pleonazmów w cs. redakcjach psałterzowych, tj. nieuzasadnione bezpośrednim bądź pośrednim źródłem ich zastosowanie odnotowuje się jako rzadkość, por. Ps 144[143]:12; kwestia ta jednak wymaga dalszych badań; okazać się bowiem może, że młodsze psałterze cs. używają pleonazmów jeszcze w innych niż scs. Psałterz synajski partiach tekstu, co przemawiałoby za szerszym, nie tylko wyjątkowym, usamodzielnieniem się na gruncie cerkiewnosłowiańskim tej biblijnej struktury stylistycznej.

\section{Lista skrótów}

BPK - Biblia Pierwszego Kościoła (Popowski, 2017).

BT - Biblia Tysiąclecia (Stachowiak \& Romaniuk, 1980).

EJO - Encyklopedia językoznawstwa ogólnego (Polański, 2003).

EJP - Encyklopedia języka polskiego (Urbańczyk \& Kucała, 1999).

G-PSS - Grecko-polski słownik Stronga (Strong, 2015).

H-PiA-PSS - Hebrajsko-polski i aramejsko-polski słownik Stronga (Strong, 2017).

H-PST (Pięcioksiąg) - Hebrajsko-polski Stary Testament: Pięcioksiąg, 2017.

H-PST (Pisma) - Hebrajsko-polski Stary Testament: Pisma, 2009.

H-PST (Prorocy) - Hebrajsko-polski Stary Testament: Prorocy, 2008.

JPII/BXVI - Jan Paweł II, Benedykt XVI rozważają Psalmy i Apokalipsę św. Jana, 2006.

KB - Konkordancja biblijna (Flis, 1996). 


\begin{tabular}{|c|c|}
\hline $\mathrm{KH}-\mathrm{K}_{\mathrm{d}} \mathrm{BH}$ & - Komentarz historyczno-kulturowy do Biblii Hebrajskiej (Walton i in., 2005). \\
\hline KKB & - Katolicki komentarz biblijny (Brown i in., 2001). \\
\hline $\mathrm{LXX}_{\mathrm{RP}}$ & - Septuaginta (Popowski, 2014). \\
\hline $\mathrm{P}_{\mathrm{p}} \mathrm{B}$ & - Przewodnik po Biblii (Alexander, 1997). \\
\hline $\mathrm{RWO}_{\mathrm{d}} \mathrm{PŚ} w$ & - Rozszerzony wstęp ogólny do Pisma Św., 2012. \\
\hline SG-P $P_{1-2}$ & - Słownik grecko-polski (Jurewicz, 2000-2001). \\
\hline SJS/CCЯ & - Словарь старославянского языка, 2006. \\
\hline SJS $_{\mathrm{ac}}$ & - Slovník jazyka staroslověnského, 2010-2016. \\
\hline SSB & - Słownik symboliki biblijnej (Ryken i in., 1998). \\
\hline SWO & - Słownik wyrazów obcych (Sobol, 1995). \\
\hline WSG-PNT & - Wielki słownik grecko-polski Nowego Testamentu (Popowski, 1995). \\
\hline WSH-PiA-PST & $\begin{array}{l}\text { - Wielki słownik hebrajsko-polski i aramejsko-polski Starego Testamentu } \\
\text { (Koehler i in., 2008). }\end{array}$ \\
\hline БС $\Gamma_{\text {инт. }}$ & - Библейский словарь: Б. Геие, b.d. \\
\hline БСГЛ инт. & - Библейский словарь: Профессор Николай Никанорович Глубоковский, b.d. \\
\hline БСН & - Библейский словарь Нюстрема, b.d. \\
\hline ПС & - Практическая Симфония для проповедников Слова Божия (Дьяченко, 1992). \\
\hline ПЦ-СС $\mathrm{C}_{1-2}$ & - Полньий иерковно-славянский словарь (Дьяченко, 1998). \\
\hline СиОСП & - Справочный и объяснительный словарь к псалтири (Гильтебрандт, 1993). \\
\hline $\mathrm{CC}$ & - Старославянский словарь (Цейтлин і in., 1999). \\
\hline TEM(Мих. $)_{\text {инт. }}$ & - Толкование на Евангелие от Матфея: Епископ Михаил (Лузин), b.d. \\
\hline ТП(Ирин. $)_{\text {инт. }}$ & $\begin{array}{l}\text { - Толкование на Псалтирь, по тексту еврейскому и греческому: Архи- } \\
\text { епископ Ириней (Клементьевский), b.d. }\end{array}$ \\
\hline ТП(Лоп.) инт. & - Толкование на Псалтирь: Профессор Александр Павлович Лопухин, b.d. \\
\hline ТП(Пал.) инт. & - Толкование на Псалмь: Епископ Палладий (Пьянков), b.d. \\
\hline
\end{tabular}

\section{Psałterzowe teksty porównawcze}

B.

- Болонски псалтир (Дуйчев, 1968).

C.

- Psałterz metropolity Cypriana, XV w. [w zestawieniu wariantów lekcji z wyd.: Чешко i in., 1989].

F.

- Ruski psałterz rękopiśmienny, XIII w. (b.d.).

$\mathrm{BH}$

- Psałterz hebrajski [w wyd.: Hebrajsko-polski Stary Testament: Pisma, 2009; Biblia Hebrajska, wersja interlinearna, b.d.].

LXX - Psałterz grecki [w wyd.: Rahlfs, 2006].

N.

- Psałterz norowski (Чешко i in., 1989). 
S.

Sr.

T.
- Psałterz synajski (Северьянов, 1954 [Pss. 1-137]; Mareš, 1997 [Pss. 138-151]).

- Psałterz serbski (Altbauer, 1997 [Pss. 37:7-151]; Tarnanidis, 1988 [Pss. 1-7:6, 17:28-20:10, 24:2-27]).

- Psałterz Tomicza (Джурова, 1990).

\section{Bibliografia}

Alexander, D., \& Alexander, P. (Red.). (1997). Przewodnik po Biblii [ $\left.\mathrm{P}_{\mathrm{p}} \mathrm{B}\right]$ (T. Mieszkowski, Tłum. \& Red.). Oficyna Wydawnicza „Vocatio”. (Oryginalna praca opublikowana 1993).

Altbauer, M. (2002a). O kryteriach ustalania pierwowzoru tłumaczeń biblijnych (Na przykładzie wschodniosłowiańskiego tłumaczenia Księgi Ruty). W M. Altbauer, Wzajemne wptywy polsko-żydowskie w dziedzinie językowej (M. Brzezina, Wyb. \& Oprac.; ss. 65-76). Polska Akademia Umiejętności.

Altbauer, M. (2002b). O pewnej funkcji nieodmiennego imiesłowu czynnego czasu teraźniejszego w polszczyźnie. W M. Altbauer, Wzajemne wptywy polsko-żydowskie w dziedzinie jezzykowej (M. Brzezina, Wyb. \& Oprac.; ss. 43-47). Polska Akademia Umiejętności.

Altbauer, M. (2002c). O technice przekładowej Szymona Budnego. W M. Altbauer, Wzajemne wplywy polsko-żydowskie w dziedzinie językowej (M. Brzezina, Wyb. \& Oprac.; ss. 55-64). Polska Akademia Umiejętności.

Arnold, B. T., \& Choi, J. H. (2008). A guide to Biblical Hebrew syntax. Cambridge University Press. Bieńkowska, D. (2002). Polski styl biblijny. Archidiecezjalne Wydawnictwo Łódzkie.

Briks, P. (2013). Ksiega Jonasza: Przewodnik po tekście hebrajskim. https://docplayer.pl/1345575 -Ksiega-jonasza-przewodnik-po-tekscie-hebrajskim-piotr-briks-briks-op-pl.html

Brown, R. E., Fitzmyer, J. A., \& Murphy, R. E. (Red.). (2001). Katolicki komentarz biblijny [KKB] (K. Bardski i in., Tłum.). Oficyna Wydawnicza „Vocatio”. (Oryginalna praca opublikowana 1990).

Flis, J. (1996). Konkordancja biblijna do Pisma Świętego Starego i Nowego Testamentu Biblii Tysiaclecia [KB]. Oficyna Wydawnicza „Vocatio”.

Hebrajsko-polski Stary Testament: Pięcioksiag: Przekład interlinearny z kodami gramatycznymi, transliteracją oraz indeksem rdzeni [H-PST (Pięcioksiąg)] (A. Kuśmirek, Oprac. \& Wstęp). (2017). Oficyna Wydawnicza „Vocatio”.

Hebrajsko-polski Stary Testament: Pisma: Przekład interlinearny z kodami gramatycznymi, transliteracja $i$ indeksem stów hebrajskich $i$ aramejskich [H-PST (Pisma)] (A. Kuśmirek, Oprac. \& Wstęp). (2009). Oficyna Wydawnicza „Vocatio”.

Hebrajsko-polski Stary Testament: Prorocy: Przekład interlinearny z kodami gramatycznymi, transliteracją i indeksem stów hebrajskich [H-PST (Prorocy)] (A. Kuśmirek, Oprac. \& Wstęp). (2008). Oficyna Wydawnicza „Vocatio”.

Jan Paweł II, Benedykt XVI rozważaja Psalmy i Apokalipsę św. Jana [JPII/BXVI]. (2006). Oficyna Wydawnicza „Vocatio”. 
Jurewicz, O. (2000-2001). Słownik grecko-polski [SG-P 1-2 $_{\text {] }}$ (T. 1-2). Wydawnictwo Szkolne PWN. Kata Biblon: Wiki lexicon of the Greek New Testament. (b.d.). http://lexicon.katabiblon.com /index.php?search $=80$

Koehler, L., Baumgartner, W., \& Stamm, J. J. (2008). Wielki słownik hebrajsko-polski i aramejsko-polski Starego Testamentu [WSH-PiA-PST] (P. Dec, Red.; T. 1-2). Oficyna Wydawnicza „Vocatio”. (Oryginalna praca opublikowana 2001).

Kowalska, D. (2003). Styl Psałterza floriańskiego na tle porównawczym. Archidiecezjalne Wydawnictwo Łódzkie.

Łuczak, A. (1992). Problem rozwiązywania hebraizmów i arameizmów w Nowym Testamencie S. Murzynowskiego - na wybranych przykładach. W M. Kamińska \& E. Małek (Red.), Biblia a kultura Europy (T. 1, ss. 225-231). Wydawnictwo Uniwersytetu Łódzkiego.

MacRobert, C. M. (1990). The Greek textological basis of the early redactions of the Church Slavonic Psalter. Palaeobulgarica/Старобългаристика, 14(2), 7-15.

MacRobert, C. M. (1993). Translation is interpretation: Lexical variation in the translation of the Psalter from Greek into Church Slavonic up to the 15th century. Zeitschrift für slavische Philologie, 53(2), 254-284.

MacRobert, C. M. (1998). The textual tradition of the Church Slavonic Psalter up to the fifteenth century. W J. Krašovec (Red.), Interpretation of the Bible (ss. 921-942). Sheffield Academic Press.

MacRobert, C. M. (2005). On the problem of identifying a „Preslav Redaction” of the Psalter. W M. Dimitrova, P. Petkov, \& I. Hristova (Red.), Acta palaeoslavica (T. 2, ss. 39-46). Heron Press.

Majewski, M. (2013). Jak przekłady zmieniają sens Biblii... O teorii i praktyce tłumaczenia Biblii. https://upjp2.academia.edu/MarcinMajewski

Moszyński, L. (1990). Pierwsze przejawy samodzielnego życia biblijnych struktur stylistycznych w języku staro-cerkiewno-słowiańskim. Studia z Filologii Polskiej i Słowiańskiej, 26, 187-196.

Moszyński, L. (2009). Biblia Szymona Budnego: Charakterystyka przekładu. W L. Moszyński, Przeszłość i teraźniejszość języków słowiańskich (ss. 179-194). Poznańskie Towarzystwo Przyjaciół Nauk.

Polański, K. (Red.). (2003). Encyklopedia językoznawstwa ogólnego [EJO]. Zakład Narodowy im. Ossolińskich.

Popowski, R. (1995). Wielki słownik grecko-polski Nowego Testamentu [WSG-PNT]. Oficyna Wydawnicza „Vocatio”.

Popowski, R. (2014). Septuaginta, czyli Biblia Starego Testamentu wraz z ksieggami deuterokanonicznymi i apokryfami [ $\left.\mathrm{LXX}_{\mathrm{RP}}\right]$ (2. wyd.). Oficyna Wydawnicza „Vocatio”.

Popowski, R. (2017). Biblia Pierwszego Kościoła [BPK]. Oficyna Wydawnicza „Vocatio”.

Riewzin, I. I., \& Rozencwejg, W. J. (1981). U podstaw teorii przekładu (M. Wryk, Tłum.). Pamiętnik Literacki, 72(1), 255-268. http://bazhum.muzhp.pl/czasopismo/8/?idno=11199

Rozszerzony wstęp ogólny do Pisma Św. [RWO ${ }_{\mathrm{d}} \mathrm{PŚ}$ ]. (2012). Domowy Kościół diecezji toruńskiej. http://torun.oaza.pl/dk/wp-content/uploads/2012/09/ATT00036.pdf 
Ryken, L., Wilhoit, J. C., \& Longman, T., III. (1998). Słownik symboliki biblijnej [SSB] (Z. Kościuk, Tłum.). Oficyna Wydawnicza „Vocatio”. (Oryginalna praca opublikowana 1996).

Siwek, K. (2013). Biblijny język hebrajski: Kurs podstawowy i średni. Verbinum Wydawnictwo Księży Werbistów.

Slovník jazyka staroslověnského/Lexicon linguae palaeoslovenicae: T. 5. Addenda et corrigenda [SJS $\left.{ }_{\mathrm{ac}}\right]$ (Cz. 53-60). (2010-2016). Slovanský Ústav AV ČR.

Sobol, E. (Red.). (1995). Słownik wyrazów obcych PWN [SWO] (nowe wyd.). Wydawnictwo Naukowe PWN.

Stachowiak, L., \& Romaniuk, K. (Red.). (1980). Pismo Święte Starego i Nowego Testamentu: W przekładzie z języków oryginalnych [BT] (3. wyd. popr.). Wydawnictwo Pallottinum.

Strong, J. (2015). Grecko-polski słownik Stronga z lokalizacja słów greckich i kodami Popowskiego [G-PSS] (A. Czwojdrak, Tłum.). Oficyna Wydawnicza „Vocatio”. (Oryginalna praca opublikowana 1890).

Strong, J. (2017). Hebrajsko-polski i aramejsko-polski słownik Stronga z lokalizacją słów hebrajskich i aramejskich oraz kodami Baumgartnera [H-PiA-PSS] (A. Czwojdrak, Tłum.). Oficyna Wydawnicza „Vocatio”. (Oryginalna praca opublikowana 1890).

Szulc, A. (2000). Leksykalne i słowotwórcze zróżnicowanie cerkiewnosłowiańskich psałterzy redakcji ruskiej z XI-XIX wieku: Część 1. Zróżnicowanie leksykalne. Towarzystwo Naukowe w Toruniu.

Szulc, A. (2018). O tłumaczeniach greckich $\sigma \kappa \eta \dot{v} \omega \mu \alpha, \sigma \kappa \eta v \eta$ i innych odzwierciedlonych w cerkiewnosłowiańskich redakcjach Księgi Psalmów. Slavia Meridionalis, 18, Article 1610. https://doi.org/10.11649/sm.1610

Termińska, K. (2015). Studia z hebrajszczyzny biblijnej: Niedoczytanie moje. Wydawnictwo Uniwersytetu Śląskiego.

Thomson, F. (1998). The Slavonic translation of the Old Testament. W J. Krašovec (Red.), Interpretation of the Bible (ss. 605-920). Sheffield Academic Press.

Tomal, M. (2000). Język hebrajski biblijny. Wydawnictwo Akademickie DIALOG.

Urbańczyk, S., \& Kucała, M. (Red.). (1999). Encyklopedia języka polskiego [EJP] (3. wyd. popr. i uzup.). Zakład Narodowy im. Ossolińskich.

Walton, J. H., Matthews, V. H., \& Chavalas, M. W. (2005). Komentarz historyczno-kulturowy do Biblii Hebrajskiej [KH-K $\mathrm{d} B \mathrm{H}]$ (Z. Kościuk, Tłum.). Oficyna Wydawnicza „Vocatio”. (Oryginalna praca opublikowana 2000).

Wolniewicz, M. (1994). Teoria przekładu biblijnego w ujęciu współczesnych tłumaczy „Biblii” na język polski. Łódzkie Studia Teologiczne, 3, 19-30. http://bazhum.muzhp.pl /czasopismo/803/?idvol=12705

Zdunkiewicz-Jedynak, D. (2010). Wykłady ze stylistyki. Wydawnictwo Naukowe PWN.

Библейский словарь: Б. Геие [БСГ инт.]. (b.d.). Азбука веры. https://azbyka.ru/otechnik/Spravochniki /biblejskij-slovar-gese/128

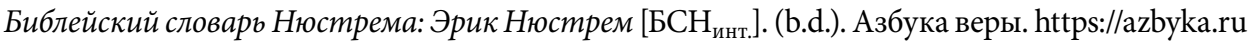
/otechnik/Spravochniki/slovar-nustrema/ 
Библейский словарь: Профессор Николай Никанорович Глубоковский [БСГлинт.]. (b.d.). Азбука веры. https://azbyka.ru/otechnik/Nikolaj_Glubokovskij/biblejskij-slovar/\#0_9

Гильтебрандт, П. А. (1993). Справочный и объяснительный словарь к псалтири [СиОСП] (H. Keipert, Wstęp). Verlag Otto Sagner. https://doi.org/10.3726/b12761 (Oryginalna praca opublikowana 1898).

Дьяченко, Г. (1992). Практическая Симфония для проповедников Слова Божия [ПС]. Изд. Свято-Троицкой Сергиевой Лавры. (Oryginalna praca opublikowana 1903).

Дьяченко, Г. (1998). Полный церковно-славянский словарь [ПЦ-СС ${ }_{1-2}$ ] (Т. 1-2). Издательский Отдел Московского Патриархата; Терра-Книжный Клуб. (Oryginalna praca opublikowana 1900).

Карачорова, И. (1985). Редакции древнеболгарского текста Псалтыри по языковым данным.

[W Е. Коцева, И. Карачорова, \& А. Атанасов, Некоторые особенности славянских псалтырей на материале XI-XVI вв.]. Полата кънигописьная, 14-15, 26-38.

Кузова, М. (2013). Экспрессия устойчивой тавтологии в русском и болгарском языках. W E. Стоянова et al. (Red.), Русистика 2013: Сборник материалов международной научной конферениии „Русистика ХХІ века: традиции и перспективы” (ss. 113-122). Издателтво Химера. https:/www.shu.bg/wp-content/uploads/file-manager-advanced /users/faculties/fhn/izdaniya/rusistika/Rusistika_2013.pdf

Погорелов, В. (1901). Псалтыри: С приложением статьи: „О редакциях славянского перевода Псалтыри" и четырех фототипических таблии. Синодальная Типография.

Словарь старославянского языка [SJS/CCЯ] (Т. 1-4). (2006). Санкт-Петербургский государственный университет. (Oryginalna praca opublikowana 1958-1997).

Толкование на Евангелие от Матфея: Епископ Михаил (Лузин) [ТЕМ(Мих.) инт.]. (b.d.). Азбука веры. https://azbyka.ru/otechnik/Mihail_Luzin/tolkovanie-na-evangelie-ot -matfeja/25

Толкование на Псалмы: Епископ Палладий (Пьянков) [ТП(Пал.) инт.]. (b.d.). Азбука веры. https://azbyka.ru/otechnik/Palladij_Pyankov/tolkovanie-na-psalmy/

Толкование на Псалтирь, по тексту еврейскому и греческому: Архиепископ Ириней

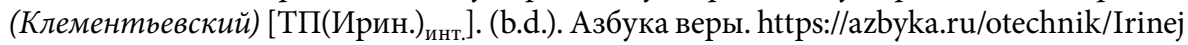
_Klementevskij/tolkovanie-na-psaltir-po-tekstu-evrejskomu-i-grecheskomu/143

Толкование на Псалтирь: Профессор Александр Павлович Лопухин [ТП(Лоп.) Азбука веры. https://azbyka.ru/otechnik/Lopuhin/tolkovaja_biblija_22/147

Цейтлин, Р. М., Вечерка, Р., \& Благова, Э. (Red.). (1999). Старославянский словарв: По рукописям $X-X I$ веков [CС]. Русский язык.

Чешко, Е. В. (1981). Второе южнославянское влияние в редакции псалтырного текста на Руси (XIV-XV вв.). Palaeobulgarica/Старобългаристика, 5(4), 79-85.

Чешко, Е. В. (1982). Об афонской редакции славянского перевода Псалтыри в ее отношении к другим редакциям. W Е. И. Демина, Д. Иванова-Мирчева, А. Минчева, \& Е. В. Чешко (Red.), Язык и письменность среднеболгарского периода (ss. 60-93). Издательство „Наука”.

Чешко, Е. В. (1988). Кирилло-мефодиевский перевод Псалтыри и среднеболгарские правленые редакции: Структура слова и реляционные элементы. Studia Slavico-Byzantina et Mediaevalia Europensia, 1, 217-230. 


\section{Psałterzowe teksty porównawcze}

Altbauer, M. (1979). Der älteste serbische Psalter. Böhlau Verlag.

Biblia Hebrajska, wersja interlinearna. (b.d.). http://bibliaapologety.com/\#WLC

Mareš, F. V. (Red.). (1997). Psalterii Sinaitici pars nova (monasterii s. Catharinae codex slav. 2/N). Verl. der Österreichischen Akad. der Wissenschaften.

[Psałterz metropolity Cypriana, XV w.] (1989). W Е. В. Чешко, И. К. Бунина, В. А. Дыбо, О. А. Князевская, \& Л. А. Науменко, Норовская псалтырь: Среднеболгарская рукопись $X I V$ века (Cz. 1-2). Издательство Болгарской академии наук.

Rahlfs, A. (Red.). (2006). Septuaginta: Id est Vetus Testamentum graece iuxta LXX interpretes: Editio altera, quam recognovit et emendavit Robert Hanhard: Duo volumina in uno. Deutsche Bibelgesellschaft. https://pl.scribd.com/document/355377280/ SEPTUAGINTA-SBL-pdf

[Ruski psałterz rękopiśmienny, XIII w.]. (b.d.). Российская национальная библиотека (Sygnatura F.п.I.1), Санкт-Петербург.

Tarnanidis, I. (1988). The Slavonic manuscripts discovered in 1975 at St. Catherine's Monastery on Mount Sinai. Hellenic Association for Slavic Studies.

Джурова, А. (1990). Томичов псалтир (Т. 1-2). Университетско изд-во „Климент Охридски”.

Дуйчев, И. (1968). Болонски псалтир: Български книжовен паметник от ХІІІ век. Издателство на Българската академия на науките.

Северьянов, С. (1954). Синайская псалтырь: Глаголический памятник ХІ века. Akademische Druck- und Verlagsanstalt. (Oryginalna praca opublikowana 1922).

Чешко, Е. В., Бунина, И. К., Дыбо, В. А., Князевская, О. А., \& Науменко, Л. А. (1989). Норовская псалтырь: Среднеболгарская рукопись XIV века (Cz. 1-2). Издательство Болгарской академии наук.

\section{Bibliography (Transliteration)}

Alexander, D., \& Alexander, P. (Eds.). (1997). Przewodnik po Biblii [ $\left.\mathrm{P}_{\mathrm{p}} \mathrm{B}\right]$ (T. Mieszkowski, Trans. \& Ed.). Oficyna Wydawnicza "Vocatio". (Original work published 1993).

Altbauer, M. (2002a). O kryteriach ustalania pierwowzoru tłumaczeń biblijnych (Na przykładzie wschodniosłowiańskiego tłumaczenia Księgi Ruty). In M. Altbauer, Wzajemne wpływy polsko-żydowskie w dziedzinie językowej (M. Brzezina, Selection \& Ed.; pp. 65-76). Polska Akademia Umiejętności.

Altbauer, M. (2002b). O pewnej funkcji nieodmiennego imiesłowu czynnego czasu teraźniejszego w polszczyźnie. In M. Altbauer, Wzajemne wpływy polsko-żydowskie $w$ dziedzinie językowej (M. Brzezina, Selection \& Ed.; pp. 43-47). Polska Akademia Umiejętności.

Altbauer, M. (2002c). O technice przekładowej Szymona Budnego. In M. Altbauer, Wzajemne wplywy polsko-żydowskie w dziedzinie językowej (M. Brzezina, Selection \& Ed.; pp. 55-64). Polska Akademia Umiejętności. 
Arnold, B. T., \& Choi, J. H. (2008). A guide to Biblical Hebrew syntax. Cambridge University Press.

Bibleŭskiu slovar': B. Getse $\left[\mathrm{BSG}_{\mathrm{int}}\right.$ ]. (n.d.). Azbuka very. https://azbyka.ru/otechnik/Spravochniki /biblejskij-slovar-gese/128

Bibleǔskiŭ slovar' Niustrema: Érik Niustrem [BSN $\left.{ }_{\text {int. }}\right]$. (n.d.). Azbuka very. https://azbyka.ru/otechnik /Spravochniki/slovar-nustrema/

Bibleı̌skiı̆ slovar': Professor Nikolaĭ Nikanorovich Glubokovskiŭ [BSGl ${ }_{\text {int. }}$. (n.d.). Azbuka very. https://azbyka.ru/otechnik/Nikolaj_Glubokovskij/biblejskij-slovar/\#0_9

Bieńkowska, D. (2002). Polski styl biblijny. Archidiecezjalne Wydawnictwo Łódzkie.

Briks, P. (2013). Księga Jonasza: Przewodnik po tekście hebrajskim. https://docplayer.pl/1345575Ksiega-jonasza-przewodnik-po-tekscie-hebrajskim-piotr-briks-briks-op-pl.html

Brown, R. E., Fitzmyer, J. A., \& Murphy, R. E. (Eds.). (2001). Katolicki komentarz biblijny [KKB] (K. Bardski et al., Trans.). Oficyna Wydawnicza "Vocatio". (Original work published 1990).

Cheshko, E. V. (1981). Vtoroe iuzhnoslavianskoe vliianie v redaktsii psaltyrnogo teksta na Rusi (XIV-XV vv.). Palaeobulgarica/Starobŭlgaristika, 5(4), 79-85.

Cheshko, E. V. (1982). Ob afonskoĭ redaktsii slavianskogo perevoda Psaltyri v ee otnoshenii k drugim redaktsiiam. In E. I. Demina, D. Ivanova-Mircheva, A. Mincheva, \& E. V. Cheshko (Eds.), IAzyk i pis'mennost' srednebolgarskogo perioda (pp. 60-93). Izdatel'stvo "Nauka".

Cheshko, E. V. (1988). Kirillo-mefodievskiǔ perevod Psaltyri i srednebolgarskie pravlenye redaktsii: Struktura slova i reliatsionnye èlementy. Studia Slavico-Byzantina et Mediaevalia Europensia, 1, 217-230.

D'iachenko, G. (1992). Prakticheskaia Simfoniia dla propovednikov Slova Bozhiia [PS]. Izd. Sviato-Troitskoĭ Sergievol̆ Lavry. (Original work published 1903).

D'iachenko, G. (1998). Polnyi tserkovno-slavianskiŭ slovar' [PTS-SS $\left.{ }_{1-2}\right]$ (Vols. 1-2). Izdatel'skiǐ Otdel Moskovskogo Patriarkhata; Terra-Knizhnyı̆ Klub. (Original work published 1900).

Flis, J. (1996). Konkordancja biblijna do Pisma Świętego Starego i Nowego Testamentu Biblii Tysiaclecia [KB]. Oficyna Wydawnicza "Vocatio".

Gil'tebrandt, P. A. (1993). Spravochnyı i ob"iasnitel'nyı̆ slovar' k psaltiri [SiOSP] (H. Keipert, Introd.). Verlag Otto Sagner. https://doi.org/10.3726/b12761 (Original work published 1898).

Hebrajsko-polski Stary Testament: Pięcioksiag: Przekład interlinearny z kodami gramatycznymi, transliteracja oraz indeksem rdzeni [H-PST (Pięcioksiąg)] (A. Kuśmirek, Ed. \& Introd.). (2017). Oficyna Wydawnicza "Vocatio".

Hebrajsko-polski Stary Testament: Pisma: Przekład interlinearny z kodami gramatycznymi, transliteracja i indeksem słów hebrajskich i aramejskich [H-PST (Pisma)] (A. Kuśmirek, Ed. \& Introd.). (2009). Oficyna Wydawnicza "Vocatio".

Hebrajsko-polski Stary Testament: Prorocy: Przekład interlinearny z kodami gramatycznymi, transliteracją i indeksem słów hebrajskich [H-PST (Prorocy)] (A. Kuśmirek, Ed. \& Introd.). (2008). Oficyna Wydawnicza "Vocatio".

Jan Paweł II, Benedykt XVI rozważają Psalmy i Apokalipsę św. Jana [JPII/BXVI]. (2006). Oficyna Wydawnicza "Vocatio".

Jurewicz, O. (2000-2001). Słownik grecko-polski [SG-P ${ }_{1-2}$ ] (Vols. 1-2). Wydawnictwo Szkolne PWN. 
Karachorova, I. (1985). Redaktsii drevnebolgarskogo teksta Psaltyri po iazykovym dannym. [In E. Kotseva, I. Karachorova, \& A. Atanasov, Nekotorye osobennosti slavianskikh psaltyreĭ na materiale XI-XVI vv.]. Polata kŭnigopis'naia, 14-15, 26-38.

Kata Biblon: Wiki lexicon of the Greek New Testament. (n.d.). http://lexicon.katabiblon.com/index .php?search $=80$

Koehler, L., Baumgartner, W., \& Stamm, J. J. (2008). Wielki słownik hebrajsko-polski i aramejskopolski Starego Testamentu [WSH-PiA-PST] (P. Dec, Ed.; Vols. 1-2). Oficyna Wydawnicza "Vocatio". (Original work published 2001).

Kowalska, D. (2003). Styl Psałterza floriańskiego na tle porównawczym. Archidiecezjalne Wydawnictwo Łódzkie.

Kuzova, M. (2013). Ėkspressiia ustoĭchivoĭ tavtologii v russkom i bolgarskom iazykakh. In E. Stoianova et al. (Eds.), Rusistika 2013: Sbornik materialov mezhdunarodno i nauchnoi konferentsii "Rusistika XXI veka: traditsii i perspektivy" (pp. 113-122). Izdatelstvo Khimera. https://www.shu.bg/wp-content/uploads/file-manager-advanced/users/faculties/fhn /izdaniya/rusistika/Rusistika_2013.pdf

Łuczak, A. (1992). Problem rozwiązywania hebraizmów i arameizmów w Nowym Testamencie S. Murzynowskiego - na wybranych przykładach. In M. Kamińska \& E. Małek (Eds.), Biblia a kultura Europy (Vol. 1, pp. 225-231). Wydawnictwo Uniwersytetu Łódzkiego.

MacRobert, C. M. (1990). The Greek textological basis of the early redactions of the Church Slavonic Psalter. Palaeobulgarica/Starobǔlgaristika, 14(2), 7-15.

MacRobert, C. M. (1993). Translation is interpretation: Lexical variation in the translation of the Psalter from Greek into Church Slavonic up to the 15th century. Zeitschrift für slavische Philologie, 53(2), 254-284.

MacRobert, C. M. (1998). The textual tradition of the Church Slavonic Psalter up to the fifteenth century. In J. Krašovec (Ed.), Interpretation of the Bible (pp. 921-942). Sheffield Academic Press.

MacRobert, C. M. (2005). On the problem of identifying a "Preslav Redaction" of the Psalter. In M. Dimitrova, P. Petkov, \& I. Hristova (Eds.), Acta palaeoslavica (Vol. 2, pp. 39-46). Heron Press.

Majewski, M. (2013). Jak przekłady zmieniaja sens Biblii... O teorii i praktyce tłumaczenia Biblii. https://upjp2.academia.edu/MarcinMajewski

Moszyński, L. (1990). Pierwsze przejawy samodzielnego życia biblijnych struktur stylistycznych w języku staro-cerkiewno-słowiańskim. Studia z Filologii Polskiej i Słowiańskiej, 26, 187-196.

Moszyński, L. (2009). Biblia Szymona Budnego: Charakterystyka przekładu. In L. Moszyński, Przeszłość i teraźniejszość języków słowiańskich (pp. 179-194). Poznańskie Towarzystwo Przyjaciół Nauk.

Pogorelov, V. (1901). Psaltyri: S prilozheniem stat'i: “O redaktsiiakh slavianskogo perevoda Psaltyri" $i$ chetyrekh fototipicheskikh tablits. Sinodal'naia Tipografiia.

Polański, K. (Ed.). (2003). Encyklopedia językoznawstwa ogólnego [EJO]. Zakład Narodowy im. Ossolińskich.

Popowski, R. (1995). Wielki słownik grecko-polski Nowego Testamentu [WSG-PNT]. Oficyna Wydawnicza "Vocatio". 
Popowski, R. (2014). Septuaginta, czyli Biblia Starego Testamentu wraz z ksieggami deuterokanonicznymi i apokryfami [LXX $\mathrm{LP}_{\mathrm{RP}}$ ] (2nd ed.). Oficyna Wydawnicza "Vocatio".

Popowski, R. (2017). Biblia Pierwszego Kościoła [BPK]. Oficyna Wydawnicza "Vocatio".

Riewzin, I. I., \& Rozencwejg, W. J. (1981). U podstaw teorii przekładu (M. Wryk, Trans.). Pamiętnik Literacki, 72(1), 255-268. http://bazhum.muzhp.pl/czasopismo/8/?idno=11199

Rozszerzony wstęp ogólny do Pisma Św. [RWO $\left.\mathrm{R}_{\mathrm{d}} \mathrm{S} w\right]$. (2012). Domowy Kościół diecezji toruńskiej. http://torun.oaza.pl/dk/wp-content/uploads/2012/09/ATT00036.pdf

Ryken, L., Wilhoit, J. C., \& Longman, T., III. (1998). Słownik symboliki biblijnej [SSB] (Z. Kościuk, Trans.). Oficyna Wydawnicza "Vocatio". (Original work published 1996).

Siwek, K. (2013). Biblijny język hebrajski: Kurs podstawowy i średni. Verbinum Wydawnictwo Księży Werbistów.

Slovar' staroslavianskogo iazyka [SJS/SSIA] (Vols. 1-4). (2006). Sankt-Peterburgskiǐ gosudarstvennyı̆ universitet. (Original work published 1958-1997).

Slovník jazyka staroslověnského/Lexicon linguae palaeoslovenicae: Vol. 5. Addenda et corrigenda [SJS $\mathrm{Sac}_{\mathrm{ac}}$ (Pt. 53-60). (2010-2016). Slovanský Ústav AV ČR.

Sobol,E. (Ed.). (1995). Słownik wyrazów obcych PWN [SWO] (new ed.). Wydawnictwo Naukowe PWN.

Stachowiak, L., \& Romaniuk, K. (Eds.). (1980). Pismo Święte Starego i Nowego Testamentu: W przekładzie z języków oryginalnych [BT] (3rd ed., Rev. ed.). Wydawnictwo Pallottinum.

Strong, J. (2015). Grecko-polski słownik Stronga z lokalizacją słów greckich i kodami Popowskiego [G-PSS] (A. Czwojdrak, Trans.). Oficyna Wydawnicza "Vocatio". (Original work published 1890).

Strong, J. (2017). Hebrajsko-polski i aramejsko-polski słownik Stronga z lokalizacją słów hebrajskich i aramejskich oraz kodami Baumgartnera [H-PiA-PSS] (A. Czwojdrak, Trans.). Oficyna Wydawnicza "Vocatio". (Original work published 1890).

Szulc, A. (2000). Leksykalne i słowotwórcze zróżnicowanie cerkiewnosłowiańskich psałterzy redakcji ruskiej z XI-XIX wieku: Pt. 1. Zróżnicowanie leksykalne. Towarzystwo Naukowe w Toruniu.

Szulc, A. (2018). O tłumaczeniach greckich skēnōma, skēnē i innych odzwierciedlonych w cerkiewnosłowiańskich redakcjach Księgi Psalmów. Slavia Meridionalis, 18, Article 1610. https://doi.org/10.11649/ sm.1610

Termińska, K. (2015). Studia z hebrajszczyzny biblijnej: Niedoczytanie moje. Wydawnictwo Uniwersytetu Śląskiego.

Thomson, F. (1998). The Slavonic translation of the Old Testament. In J. Krašovec (Ed.), Interpretation of the Bible (pp.605-920). Sheffield Academic Press.

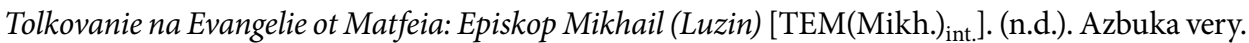
https://azbyka.ru/otechnik/Mihail_Luzin/tolkovanie-na-evangelie-ot-matfeja/25

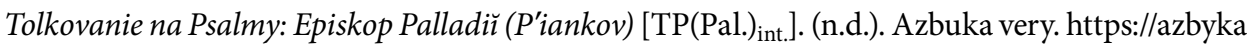
.ru/otechnik/Palladij_Pyankov/tolkovanie-na-psalmy/

Tolkovanie na Psaltir', po tekstu evreı̌skomu i grecheskomu: Arkhiepiskop Irineı̆ (Klement'evskiŭ)

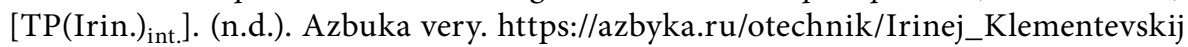
/tolkovanie-na-psaltir-po-tekstu-evrejskomu-i-grecheskomu/143 


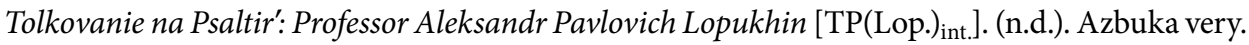
https://azbyka.ru/otechnik/Lopuhin/tolkovaja_biblija_22/147

Tomal, M. (2000). Język hebrajski biblijny. Wydawnictwo Akademickie DIALOG.

TSeĭtlin, R. M., Vecherka, R., \& Blagova, Ė. (Eds.). (1999). Staroslavianskiŭ slovar': Po rukopisiam X-XI vekov [SS]. Russkiü iazyk.

Urbańczyk, S., \& Kucała, M. (Eds.). (1999). Encyklopedia języka polskiego [EJP] (3rd ed., Rev. ed.). Zakład Narodowy im. Ossolińskich.

Walton, J. H., Matthews, V.H., \& Chavalas, M. W. (2005). Komentarz historyczno-kulturowy do Biblii Hebrajskiej [KH-K $\mathrm{d} B \mathrm{H}]$ (Z. Kościuk, Trans.). Oficyna Wydawnicza "Vocatio". (Original work published 2000).

Wolniewicz, M. (1994). Teoria przekładu biblijnego w ujęciu współczesnych tłumaczy "Biblii” na język polski. Łódzkie Studia Teologiczne, 3, 19-30. http://bazhum.muzhp.pl /czasopismo/803/?idvol=12705

Zdunkiewicz-Jedynak, D. (2010). Wykłady ze stylistyki. Wydawnictwo Naukowe PWN.

\section{List of Contrasted Psalters}

Altbauer, M. (1979). Der älteste serbische Psalter. Böhlau Verlag.

Biblia Hebrajska, wersja interlinearna. (n.d.). http://bibliaapologety.com/\#WLC

Cheshko, E. V., Bunina, I. K., Dybo, V. A., Kniazevskaia, O. A., \& Naumenko, L. A. (1989). Norovskaia psaltyr': Srednebolgarskaia rukopis' XIV veka (Pt. 1-2). Izdatel'stvo Bolgarskoŭ akademii nauk.

Duĭchev, I. (1968). Bolonski psaltir: Bŭlgarski knizhoven pametnik ot XIII vek. Izdatelstvo na Bŭlgarskata akademiia na naukite.

Dzhurova, A. (1990). Tomichov psaltir (Vols. 1-2). Universitetsko izdatelstvo "Kliment Okhridski".

Mareš, F. V. (Ed.). (1997). Psalterii Sinaitici pars nova (monasterii s. Catharinae codex slav. 2/N). Verl. der Österreichischen Akad. der Wissenschaften.

[Psałterz metropolity Cypriana, XV w.]. (1989). In E. V. Cheshko, I. K. Bunina, V. A. Dybo, O. A. Kniazevskaia, \& L. A. Naumenko, Norovskaia psaltyr': Srednebolgarskaia rukopis' XIV veka (Pt. 1-2). Izdatel'stvo Bolgarskoí akademii nauk.

Rahlfs, A. (Ed.). (2006). Septuaginta: Id est Vetus Testamentum graece iuxta LXX interpretes: Editio altera, quam recognovit et emendavit Robert Hanhard: Duo volumina in uno. Deutsche Bibelgesellschaft. https://pl.scribd.com/document/355377280/ SEPTUAGINTA-SBL-pdf

[Ruski psałterz rękopiśmienny, XIII w.]. (n.d.). Rossiǐskaia natsional'naia biblioteka (Reference code F.p.I.1), Sankt-Peterburg.

Sever'ianov, S. (1954). Sinaı̌skaia psaltyr': Glagolicheskǐ pamiatnik XI veka. Akademische Druck- und Verlagsanstalt. (Original work published 1922).

Tarnanidis, I. (1988). The Slavonic manuscripts discovered in 1975 at St. Catherine's Monastery on Mount Sinai. Hellenic Association for Slavic Studies. 


\title{
“That I may rejoice in the joy of Thy nation": On Pleonastic Constructions in Church Slavonic Redactions of the Book of Psalms
}

\author{
Summary
}

This article focuses on pleonasms extracted from the OCS Psalterium Sinaiticum and investigates their preservation in later representatives of successive CS Psalter redactions. In order to examine the use of the constructions under scrutiny, the $(\mathrm{O}) \mathrm{CS}$ Psalters have been compared with one another and with the Greek and the Hebrew patterns of translation. The study provides a detailed description of lexical choices with respect to pleonasms present in selected contexts of the Psalter. It also considers analogical structures discussed in the literature on the subject, stressing a specifically emphatic character of (O)CS Psalter pleonasms, similar to that of their Greek and Hebrew equivalents. As observed, the use of pleonasms in the compared (O)CS Psalters is distinctly consistent and generally based on the Greek/Hebrew sources. Cases that could testify to these Biblical stylistic structures having already become independent on the Slavic ground are noted as exceptions.

\section{„Obym się rozradował w rozradowaniu ludów \\ Twoich". Rzecz o konstrukcjach pleonastycznych w cerkiewnosłowiańskich redakcjach Księgi Psalmów}

\section{Streszczenie}

Artykuł koncentruje się na pleonazmach wyekscerpowanych ze staro-cerkiewno-słowiańskiego Psałterza synajskiego. Ma na celu zbadanie ich zachowawczości w młodszych reprezentantach kolejnych cerkiewnosłowiańskich redakcji psałterzowych. Teksty (s)cs. psałterzy porównano między sobą oraz z greckimi i hebrajskimi wzorcami przekładowymi pod kątem użycia rozpa- 
trywanych konstrukcji pleonastycznych. Szerzej opisano leksykalny wybór w odniesieniu do pleonazmów obecnych w wybranych kontekstach Psałterza. Uwagę poświęcono także analogicznym strukturom omówionym w literaturze przedmiotu. Podkreślono specyficzny emfatyczny charakter (s)cs. pleonazmów psałterzowych, podobny do ich grecko-hebrajskich ekwiwalentów. Wskazano na wyraźną zgodność co do użyć konstrukcji pleonastycznych w porównywanych (s)cs. psałterzach, z reguły uzasadnioną greckim/hebrajskim wzorcem (wzorcami). Przypadki mogące świadczyć o usamodzielnieniu się na gruncie słowiańskim analizowanych biblijnych struktur stylistycznych odnotowuje się jako wyjątki.

Keywords: Old Church Slavonic Psalterium Sinaiticum; Church Slavonic Psalter redaction; pleonasm; tautology; Greek (Hebrew) pattern; emphasis; cognate (internal, absolute) accusative; lexical choice

Słowa kluczowe: staro-cerkiewno-słowiański Psałterz synajski; psałterzowa redakcja cerkiewnosłowiańska; pleonazm; tautologia; wzorzec grecki (hebrajski); emfaza; biernik pokrewny (wewnętrzny, niezależny); wybór leksykalny

Arleta Szulc, Nicolaus Copernicus University in Toruń, Toruń, Poland

ORCID: https://orcid.org/0000-0003-1613-2895

Correspondence: letty@umk.pl

The preparation of this article was self-financed by the author.

Competing interests: The author has declared that she has no competing interests. 